\title{
Ivan Novik
}

National Academy of Sciences of Belarus, Minsk (Belarus)

Email: novik.jan@gmail.com

ORCID: https://orcid.org/0000-0002-9503-7206

\section{The Birth of Individuality from the Spirit of Belarusianness: the Life Trajectories, Conceptual and Emotional Matrices of the Belarusian Intellectual in the Novel by Viktar Vaĺtar Born Under Saturn}

Narodziny indywidualności z ducha białoruskości: trajektorie życia oraz koncepcyjne i emocjonalne matryce białoruskiego intelektualisty w powieści Wiktora Waltera "Urodzeni pod Saturnem”

Нараджэнне індывідуальнасці з духу беларушчыны:жыциёвыя траекторыі і каниэптуальнаэмацыйныя матрыцы беларускага інтэлігента ў рамане Віктара Вальтара „Роджаныя пад Сатурнам"

\section{Abstract}

The article is devoted to an analysis of the novel by Viktar Vaítar Rodžanyja pad Saturnam (Born under Saturn), describing the life and ideological collisions of the Belarusian students of inter-war Prague. This novel lifts the veil not only from over the conceptual world within which the Belarusian intellectual youth of those times lived, but also of emotional performance of this concepts. Born under Saturn gives us the opportunity to feel and hear the intonation from which the concepts of 'homeland', 'intelligentsia' had been pronounced. The reconstruction of this distinctive intonation, and the semantic, existential, psychological and social foundations on which it was based, forms the main goal of this research.

We view this novel as a continuation of the tradition of the polyphonic (in the terminology of Mikhail Bakhtin) philosophical novel, where philosophical concepts and theories are not simply presented, but are given in a dialogic context. Proceeding from such understanding, as the main interpretative strategy, we chose a two-aspect approach: we consider the text from the point of view of intellectual history and within the framework of the 'history of emotions'. The main ideas of the novel were analysed both in their conceptual semantics and as emotional matrices of the Belarusian intellectual of the 1920s.

One of our main findings is as the following: the tragedy of Tuhoŭski (the novel's protagonist) is a tragedy of the first generation of the Belarusian intelligentsia, of the burden of becoming oneself, after separation from the navel of traditional society and the collision with new anthropological knowledge, the violence of history and the aporia of national and social ideology.

Keywords: Viktar Vaĺtar, Rodžanyja pad Saturnam (Born under Saturn), history of emotions, the concept of 'Homeland', the concept of 'Intelligentsia' 


\begin{abstract}
Abstrakt
Artykuł poświęcono analizie powieści Wiktora Waltera Urodzeni pod Saturnem (Роджанья пад Сатурнам), орisującej życie i dylematy ideologiczne białoruskich studentów w międzywojennej Pradze. Wybór przedmiotu badań jest nieprzypadkowy: analizowany utwór posiada wysoką wartość artystyczną, nie był dotąd badany, ponadto w literaturze nie ustalono roli, jaką odegrała Praga w historii rozwoju życia intelektualnego na Białorusi w latach 20. XX w. Utwór opisuje nie tylko świat wartości, jakimi żyła ówczesna młodzież inteligencka, ale także jej kondycję psychiczną. Urodzeni pod Saturnem pokazuje także, w jaki sposób studenci białoruscy rozumieli takie pojęcia, jak „ojczyzna” i ,inteligencja”, jak wyobrażali sobie przyszłość oraz swoje powołanie. I to właśnie rekonstrukcja płaszczyzn semantycznej, egzystencjalnej, psychologicznej i społecznej była głównym celem badania. W utworze Urodzeni pod Saturnem autor nawiązuje do tradycji powieści polifonicznej (według terminologii Michała Bachtina), prezentującej koncepcje i teorie filozoficzne w wypowiedziach bohaterów. Dlatego też główną strategią badawczą zastosowaną w niniejszym artykule jest podejście łączące ze sobą historię idei oraz tzw. historię emocji. Przeprowadzone analizy doprowadziły do konstatacji, że tragedia Tuchowskiego, głównego bohatera powieści, jest także tragedią pierwszego pokolenia białoruskiej inteligencji. Pokolenie to musiało udźwignąć ciężar odkrywania własnej indywidualności w sytuacji zerwania związku z modelem tradycyjnym preferowanym przez zbiorowość, jak również wzięło na siebie obowiązek konfrontacji z: nową ideologią narodowo-społeczną, pogwałceniem historii oraz koniecznością określenia własnej roli w świecie.
\end{abstract}

Słowa kluczowe: Wiktor Walter, Urodzeni pod Saturnem, historia emocji, koncept „ojczyzna”, koncept ,ineteligencja”

\title{
Анатацыя
}

Артыкул прысвечаны аналізу рамана Віктара Вальтара Роджаныл пад Сатурнам, які апісвае жыццёвыя і ідэалагічныя калізіі беларускага студэнцтва міжваеннай Прагі. Гэты раман прыадчыняе дзверы не толькі ў канцэптуальны свет, якім жыла беларуская інтэлігенцкая моладзь тых часоў, але і ў ягонае эмацыйнае спаўненне. Роджаныя nad Сатурнам даюць нам магчымасць адчуць і пачуць як - 3 якой інтанацыяй, у якіх кантэкстах і ў адказ на якія калізіі - беларускія студэнты прамаўлялі канцэпты „бацькаўшчына”, „інтэлігенцыя”, якой мроілася ім будучыня і ў чым адчувалі яны сваё пакліканне. Менавіта рэканструкцыя гэтай адметнай інтанацыі, а таксама схаваных у ёй семантычных, экзістэнцыяльных, псіхалагічных і сацыяльных падстаў, і была галоўнай мэтай дадзенага даследавання.

Мы разглядаем Роджаныя пад Сатурнам як працяг традыцыі поліфанічнага (па тэрміналогіі Міхаіла Бахціна) філасофскага рамана, дзе філасофскія канцэпты і тэорыі не проста выкладаюцца, але даюцца ў жывым дыялагічным кантэксце. Зыходзячы 3 такога разумення, у якасці асноўнай інтэрпрэтатыўнай стратэгіi намі быў абраны двухаспектны падыход: мы разглядаем тэкст і з пункту гледжання інтэлектуальнай гісторы, і ў рамках такога падыходу як „гісторыя эмоцый”. Асноўныя ідэі рамана мы аналізавалі і ў іх канцэптуальнай семантыцы, і як эмацыйныя матрыцы беларускага інтэлігента 20-х гг. ХХ ст. 
Адной з галоўных нашых высноваў ёсць наступная: трагедыя Тугоўскага, галоўнага героя рамана - гэта трагедыя першага пакалення беларускай інтэлігенцыі, уцялесненне цяжару станаўлення самім сабой пасля адрыву ад пупавіны традыцыйнага грамадства i сутыкнення 3 новай антрапалагічнай ведай, гвалтам гісторыі і апорыямі тагачаснай нацыянальнай і сацыяльнай ідэалогіi.

Ключавыя словы: Віктар Вальтар, Роджаныя пад Сатурнам, гісторыя эмоцый, канцэпт „бацькаўшчыны”, канцэпт „інтэлігенцыі”

\section{Introduction}

If the author of these lines shared with the main character of the novel Rodzhanyja pad Saturnam (Born under Saturn) his belief in the immutability and belonging of all that is earthly to 'the starry sky above us', then perhaps it would not be necessary to look for the better beginning for our text than the following: 'the novel Born under Saturn, probably, was itself created under some special star...'. Being not, fortunately or unfortunately, fans of astrology, we should emphasize the fact: it is difficult to resist the temptation and not see the image in advance and above outlined destiny in the history of this novel. It 'is floating to the surface' almost magically - just when it could find the most grateful reader, if it could maximally get into the nerve of Belarusian everyday life, when it was most in tune with the conjuncture of the time. The novel is as consistent with the Belarusian nineties, when it was first printed, as it is not similar to the 1920 s, when it was written.

First of all, we have got an urban novel (at least, according to the 'physical' localization of the events described in the text) - the village, even if it is present in it, is only as a half-imaginary, 'designed' reference horizon, while the whole 'real' story is set in the streets of Prague and is saturated with the life of a large city. Belarus and everything that is modern Belarusian or Belarusianness - it is also an urban phenomenon, all the significant events of the last decades almost completely coincide with the cartography of Minsk and other major cities of the Republic, and once the main Belarusian 'chronotope', 'the village', slowly and inevitably goes into nonexistence from both literary and social perspectives.

Secondly, it is a novel about intellectuals and students. This work is about the special loneliness of an intellectual who has nothing to rely on in life except his own ideas and theories, where 'community' is only the name for another group based on political interests. The real village community, with its density of interpersonal connections and pre-determined social trajectories, remained somewhere out there - on the other side of the Czech border and the scene of the novel. It is a novel about 'eternal' students who, even at twenty-four' ${ }^{1}$, are still sensitive young men who are looking for their way in life and are just beginning to dream about a woman. And in this Born under Saturn

1 The age of the main character Piotr Tuhoŭski (see Val'tar, 2009, p. 192). 
resonates much more with the present than with the Belarusian 1920s - the time of young old men, when at twenty-four you could already have behind you the experience of war (or even wars), and the experience of managing your own business and, even, political management.

Thirdly, a special tragedy of bielaruščyna is unfolding in Born under Saturn: when her ideals are not broken against the monolithic blocks of totalitarian regimes and beyond the human scale of historical events, but gradually rust in the slush of everyday life, and the desired unity of the Belarusian intelligentsia is gradually destroyed by the difference of political preferences and interpersonal conflicts. It's not bielaruščyna, which is threatened, not by the 'fire and water' of repressions and political persecution, but Belarusianness, which must be carried through 'brass pipes', concerns about 'daily bread', through the temptation of petty-bourgeois peace and personal career.

Although Viktar Valtar is the actual author - as if calling the modern reader to 'follow me, and leave the dead to bury their dead' - we in our interpretation have just decided to go against this call. First of all, we shall be interested in the historicity of the novel, and what is essential in it we leave to find and think out to our living contemporaries.

In what sense can Born under Saturn be regarded as historical evidence? Of course, we are not talking about the evident answer to the question: this is one of the works of Belarusian literature of the 1920s, which together form the appropriate 'whole': actually 'Belarusian literature' as a research field. The question should be understood as follows: can the novel by Valtar in its singularity be considered as a reflection of a certain whole? The answer lies in the genre of the work.

Most researchers agree that this is a philosophical novel (Paškevič, 2002, p. 28; Baroǔka, 2014, p. 72, 75, 77; Ščur, 2011, p. 588)2, therefore, it should in a certain way reflect the worldview of the West Belarusian intelligentsia of the 1920s, including its philosophical implementations. Indeed, we find here the socio-political statements and ideological considerations and beliefs of famous figures of the Belarusian movement the prototypes of the novel's heroes (Janka Stankievič, Tamaš Hryb, Piotr Kračevski), and those political groups (monarchists and supporters of indivisible Russian culture, 'right' nationalists, socialists-revolutionaries, mildly leftists and radicals-Marxists),

2 We also agree with this definition. Substantial arguments in its favour we shall announce a little below, while we list the formal arguments: first, the adjectives 'philosophy', 'philosopher' and their derivatives appear on the pages of the novel exactly twenty times (see: Val'tar 2009, p. 92, 96, 97, 102, 107, 124, 127 (twice), 132, 141, 147, 159, 167, 170, 188, 192, 204, 215, 233, 236) and this is probably the most frequent use of the word 'philosophy' among all known Belarusian novels, secondly, as is known, over the entrance to the present philosophy wrote three names: 'Nietzsche, Freud, Marx' - direct and indirect references to Nietzsche and Marx can be found many times on the pages of Born under Saturn and what is more important, the main 'conceptual heroes' of the novel are: the thirst for power, social inequality, sexual relations, and their mutual intersections - they are constantly discussed and comprehended in the text, in student rooms, over glasses of beer with a friend, in a tense internal monologue. 
into which the Belarusian students of Prague gradually split, into which the once unified Belarusian community of interwar Czechoslovakia disintegrated. Therefore, it would seem that there is nothing easier than to write out the appropriate remarks of the right characters and to analyse them in the context of the relevant political position and ideology. But: Born under Saturn is a philosophical novel in the sense in which Dostoevskii's works are philosophical novels. Philosophical ideas and theories are not just voiced, put into the mouth of the characters or taken as a principle of plot construction, they are embodied, tested in life and at the cost of life for the characters of the text:

I цяпер яго ўласнае жыццё стала не больш, як толькі праверкай тэорыі. Ён згубіў ужо тую непасрэднасць пачуццяў, тую жывасць адчуванняў, якая бывае ў жывога, зацікаўленага жыццём чалавека; другімі словамі, ён глядзеў на жыццё, як даследчык глядзіць на марскую свінку, робячы над ёй розныя аперацыі. Яго не цікавіць самая свінка, яе пачуцці, радасці і болі, а цікавіць, як адпраўляюцца функцыі яе органаў згодна ягонай тэорыі ${ }^{3}$ (Val'tar, 2009, p. 125).

The heroes of such novels do not express ideas - they are obsessed with them. Ideas here are not brought by deductive constructions, in their name and guided by their distinctive 'logic' they kill an old pawnbroker or commit suicide. In a certain sense, the protagonist of Born under Saturn - Piotr Tuhoŭski - decides on both: he becomes a terrorist, though unsuccessful, looking for his own death and wanting to kill others, for the sake of his theory - he was born a 'sparrow' as opposed to 'vultures': an unhappy man who should not hope for anything good in life, does not have to wait for any benefits from life.

But just from the 150-year history of exegesis and attempts at reception of the Russian philosophical novel, the paradox is well known: the words and thoughts of Dostoevskii's heroes - so convincing, capacious and exciting - turn into the banal whenever we try to quote them out of the general context, as complete, independent philosophical thoughts, divorced from the actions of the hero, his distinctive intonation, without dialogical opposition to other views, to another worldview. However, it does not make sense to develop especially this topic - better and more than Bakhtin, we are unlikely to say (Bahtin, 2016). And let it seem at a superficial glance: in Born under Saturn the author gives 'freedom' to sound fully to only one voice - that of Piotr Tuhoŭski, but it is not difficult to find in his monologues, to see the very polyphony, which was written about in his time by the Russian philosopher: polyphony, which could not be transferred to the monological philosophical partita without losing meaning. For example:

\footnotetext{
'And now his own life has become nothing more than a test of theory. He had already lost that spontaneity of feeling, that vivacity of sensation, which is the case with a living, interested person; in other words, he looked at life as an investigator looks at a guinea pig, making various operations on it. Not interested in the pig, its feelings, joy and pain, but is interested in how the functions of its organs act according to his theory'.
} 
Так! - паўтарыў Тугоўскі. - Нашто жыць?! Папрабуйце жыць з боллю ў сэрцы, 3 раненай свядомасцю, 3 разбітымі крыламі... Папрабуйце разбівацца штодня аб жыццёвыя абставіны, як хвалі разбіваюцца аб скалы... Жыць! - хацеў ён сказаць усім гэтым людзям, якія несліся міма і насмешліва на яго паглядалі. - Каб перанасіць вашыя насмешкі - жыць... Вы кажаце: „Жыць...” - і зараз пускаеце ў ход свае філасофіі, ад якіх пахне смерцю і трупамі. Вы кажаце: „Цярпіце! Цярпеннем усё ачышчаецца!” Вы смеяцеся над тымі, якія канчаюць жыццё, завеце іх дурнямі. Вялікі філосаф Ніцшэ сказаў: „Вы кажаце, што жыццё - бяссэнсіца? Правідлова!... Так паспрабуйце скончыць гэту „бяссэнсіцу”!4 (Val'tar, 2009, p. 92).

We do not see the reflections, but the deductive finishing of thought - Tuhoŭski passionately and persistently, with anguish 'argues' with voices of passers-by, 'ordinary' people which sound in his head. He tries to foresee possible arguments against his thoughts, he himself voices these arguments with the supposed intonation of imaginary interlocutors, and he himself dismisses these arguments condensed into their philosophy of life. He opposes to his prospective listeners, again, not just arguments, logical challenges, but the words of Nietzsche, behind which one can guess the holistic position of life, the particular worldview of the German philosopher.

Here is another example. Tuhoŭski, once again disappointed in his life, over a glass of beer is talking to his friend 'father' Kiryl Buračeŭvski:

Слухай, айцец Кірыла, - прамовіў Тугоўскі з бліснуўшымі слязінкамі на вачох. Не старайся мяне пераконваць. Я ўсё ўжо ўзважыў, усё падлічыў. Падвёў усе балансы ў той момант, калі быў адзін па начох у сваёй альтане. Ведаеш, ёсць моманты, больш важныя за хлеб, за ежу, за стыпендыю. Ёсць моманты, калі не хочацца ні піць, ні есць. Ты, напэўна, чуў, што ў турме часам арыштанты аб'яўляюць галадоўку? Так вось, брат: значыць, ёсць мукі і больш цяжкія, чым голад, ёсць так званыя й маральныя мукі. Вось гэтыя мукі прымушаюць мяне адмовіцца ад стыпенды. Ты робіш зноў здзіўлены твар... Ну добра... Дапусцім, што я згаджуся атрымаць стыпендыю, стану студэнтам. Ну й што пасля гэтага? Жыць, калі ты чуеш поўны ўпадак сіл, калі ў цябе баліць сэрца, мучыцца свядомасць... Слухай, айцец Кірыла: жыць без таленту, без аднаго хоць якоганебудзь таленту, жыць разачараванаму ў самім сабе, жыць 3 пэўнасцю, што табе ўсё роўна нічога не ўдасца, згадзіся сам - немагчыма ${ }^{5}$ (Val'tar, 2009, pp. 123-124).

4 'Yes! - repeated Tuhouski. - Why live?! Try to live with the pain in the heart, with a broken mind, with broken wings... Try to break daily on life circumstances as waves break on rocks... Live! - he wanted to say to all those people who were rushing by and looking at him mockingly. - To bear your taunts - to live... You say: "Live..." - and now you use your philosophies, which smell of death and corpses. You say: "Be patient! Patience clears everything!" You laugh at those who end their lives, call them fools. The great philosopher Nietzsche said: "You say that life is nonsense? Correct! ... So try to end this "nonsense"!'

5 'Look, father Kiryl, - said Tuhouski with shining tears in his eyes. - Don't try to change my mind. I have already weighed everything, counted everything. I have summed up all the balances at 
This is clearly not a 'Socratic' dialogue: Tuhoŭski's aim is not to convince his interlocutor or to find together with him an abstract truth. You can 'hear' well in the words all the impetuosity and youth recklessness of Tuhoǔski, his whole 'breakdown'. When saying, 'don't try to convince me', Tuhouski asks just the opposite - praise for his determination, acceptance of his peculiarity, his ability for moral sufferings, more weighty than any material needs. In a word, Tuhoŭski's speech cannot be distinguished from the context of both his own personality and the context of his relationship to 'father' Kiryl. It is necesary to note, that from Tuhoŭski's speech his still silent companion appears 'alive' before us. The response to Tuhoǔski's words, the whole pattern of emotional reactions to his words of Kiryl Buračeǔski has already sounded directly in them (Tuhouski's words) themselves. We don't even need to hear 'father' Kiryl's own words to feel his personal presence, to forsee his answer.

Likewise Tuhoŭski constantly gets other people's words, which are not only logical, but express the whole life position, worldview of others, and inserts them into his own thoughts, his monologues ${ }^{6}$.

So it is much better for the reader: in his time Arthur Lovejoy, as one of the objects for the study of ideas by historians, postulated the so - called 'Metaphysical pathos' (Lovejoy, 1936, pp. 10-14) - all those distinctive aesthetic embellishments, rhetorical figures, with which the philosophers appealed not only to the mind of the reader, but also to his feelings, tried to awaken in him an emotional attitude to the universe. In Born under Saturn we find not only a similar 'poetics' of abstract philosophical ideas, the author's effort to adjust the reader's feelings by his own, but also a kind of 'history of emotions' (see: Rosenwein, 2006; Reddy, 2001; Zorin, 2016; Plamper, Šahadat, Èli, 2010; Plamper, 2012) of Belarusian students of interwar Prague. We have got before

moment when he was alone at night in my pavilion. You know, there are moments more important than bread, than food, than scholarship. There are moments when you do not want to drink or eat. You must have heard that in prison sometimes prisoners go on hunger strike? Now, brother, then, there are torments and more severe than hunger, there are also so-called moral torments. Those tornments makes me give up my scholarship. You again looks surprised... All right... Let's say I accept a scholarship, become a student. Well, what then? To live, if you feel completely exhausted, if your heart aches, your consciousness is suffering... Listen, father Kiryl: to live without talent, without any one talent, to live disappointed in yourself, to live with confidence that you might never manage anything, agree with me - it is impossible'.

6 See e.g.: Belarusian intellectuals as 'swallows of the Belarusian spring' - Tamaševič's words (Val'tar, 2009, p. 134), later picked up by other characters (Val'tar, 2009, pp. 168-169; 220; 235); Kiryl Buračeǔvski's specially disparaging pronunciation of the word 'intellectual' (Val'tar, 2009, p. 124; 168) then quoted by Tuhoŭski in the same key (Val'tar, 2009, p. 171; 183; 194-196; 201); in an internal monologue, Tuhoǔski repeats Tamaševič's comparison: he is Faust, and Viarchoŭskaja is Margarita (Val'tar, 2009, p. 213), in an ironic context: 'And at this time some Mephistopheles teased him, as a weak old man, Faust about the beautiful image of Margarita-Viarchoŭskaja' (Val'tar, 2009, p. 228); however, Tolstoi's 'simplification' (Val'tar, 2009, p.183; 196; 212-213; 223), and Nietzsche's words are repeated in the same modality - as a reference to the whole life philosophy of Tolstoi or Nietzsche, to their personalities. 
us not just a philosophy - socio-political and existential views, - but the philosophy dramatized, experienced in life and at the cost of life, the philosophy given in dialogue and through dialogue.

Hence the specificity of our approach to the text of V. Valtar, the peculiarity of our reading of the novel - the main ideas, concepts ${ }^{7}$ inherent in the novel, we read in their two-fold unity - and in their conceptual semantics and as a kind of "emotives" ${ }^{8}$ or 'emotional matrices's.

\section{Ground Zero: Homeland}

In the last section we have exaggerated a little, identifying the Belarusian novel of Valtar exclusively with city life. True, the reality of Born under Saturn really reminds us of Belarus of the late $20^{\text {th }}$ - early $21^{\text {st }}$ centuries - urban in its localization and spirit, intellectual and youth-student in its social supports, Belarus, which is struggling with the calm of modern history. But for Valtar's heroes, Prague streets, studies, bohemian or petty-bourgeois life are only an intermediate stop on the way back to the 'Homeland': that Belarus of the peasant community and the village landscape, Belarus as a struggle on the political and historical field for the right to be called 'people', for the very right to exist - Belarus, known to us from the literary works of Valtar's contemporaries. The majority of the Belarusian students in Prague expect to return to 'that' Belarus, and according to its needs, and in the horizon of its prospective future, they measure their life 'here' in Prague: their student and scientific successes, their political preferences and alliances. They are more emotionally, socially and existentially attached to their native 'home' there - outside the Czechoslovak border - than to the precarious modernity of 'here', the life of a major European city. To remain 'here' for them means to betray or lose.

At least, at first glance, both the reader and the heroes of Born under Saturn seem to have this common reference point, the place where all the paths of discussion and reflection converge, a common centre of attraction. But gradually the Czech students understand - everything is passing 'Мы разумеем Беларусь па-рознаму' (Val'tar, 2009 , p. 136 $)^{10}$, - shouts the main character of the novel Haliena Viarchoǔskaja. Each of the groups exists in its own coordinate system, their life paths ran parallel to each other. A continuation of Viarchoŭskaja's words, in which this difference is reflected:

7 In this text we have focused on the following concepts: homeland, history, physicality and intelligence.

8 'Emotive' - the concept introduced into scientific circulation by William Reddy is to outline the distinctive emotionally charged words that name or evoke the corresponding sensory state (Reddy, 2001).

9 'Public images of feeling without which [...] people can not only unravel their own feelings, but also experience them, we call in this book emotional matrices. A set of such matrices, together with the regulations of their social, age and gender distribution, is offered by culture' (Zorin, 2016, p. 30).

10 'We understand Belarus in different ways'. 
Янка Станкевіч думае: дайце нам незалежную Беларусь, усё роўна якую, хоць 3 княгіняй Радзівіл як каралевай на чале, хоць 3 чортам, нарэшце, абы толькі на шыльдах жыдоўскіх крам красаваліся б беларускія надпісы і ў установах гутарылі б па беларуску. Але я думаю: для беларускага селяніна і работніка такая станкевічаўская Беларусь зусім не патрэбна. Ці не ўсё роўна яму, што яго эксплуатуе расейскі і жыдоўскі капіталіст, ці што на фабрыцы будзе сядзець дырэктар фабрыкі - Янка Станкевіч - і размахваць залатым ланцужком на вялікім бруху, гутарыць па беларуску і эксплуатаваць работнікаў па старому. Я думаю, беларускі працоўны народ назаўтра пракляў бы такую Беларусь. Не, пакуль мы не зменім сацыяльных варункаў, пакуль мы не паставім у аснову нашай праграмы сацыяльнае вызваленне беларусаў, - мы будзем пустымі або беларускімі здраднікамі ${ }^{11}$ (Val'tar, 2009, p. 141).

The search for unity through belonging to a single Homeland turned into a mechanism of fragmentation of the student community. The sought-after principle, which would unite Belarus 'within its ethnographic borders' into a single whole, thus, inevitably, one way or another, pushed certain social groups beyond the boundaries of Belarusianness.

And this is one of those basic questions, the answer to which we were looking for in our analysis of Born under Saturn - on what principles the 'imagined community' (Anderson, 1991) of the Belarusian culture of the 1920s was represented, according to which constructive principles the image of the common Homeland was built: or didn't then the 'builders' of Belarus fail, laying the cornerstone, creating the image of 'Homeland', and - was it possible to create in those conditions another, not exclusive image of Belarus? Of course, an unambiguous and accurate answer to this question should not be expected immediately. But in the horizon of such request, it is necessary in our opinion, to reread Born under Saturn, because here you can not only see the 'conceptual scaffoldings' of the construction of then Belarusianness, but also 'hear' with what intonation and in what contexts the word 'Fatherland' has been pronounced.

'Litwo, Ojczyzno moja! ty jesteś jak zdrowie; // Ile cię trzeba cenić, ten tylko się

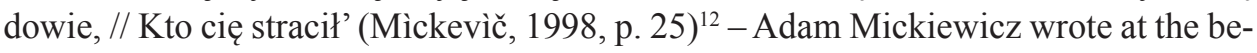

11 'Janka Stankievič thinks: give us independent Belarus, do not care what, although with Princess Radziwill in as a Queen led in, even by devil, finally, only I would like to see Belarusian calligraphy flaunted on signs of Jewish stores and in institutions they would converse in Belarusian. But I think for the Belarusian peasant and worker such a Stankievič' Belarus does not need. Does it matter to him that he is being exploited by a Russian and Jewish capitalist, or that the factory Director - Janka Stankievič - will sit in the factory and wave a gold chain on his big belly, speak Belarusian and exploit the workers in the old way. I think the Belarusian working people would curse such a Belarus tomorrow. No, as long as we do not change the social conditions, as long as we do not base our programme on the social liberation of Belarusians, we will be empty or Belarusian traitors'.

12 'Lithuania, my country, you are like health; how much you are should be prized only he can learn who has lost you' (Mickiewicz, 1917, p.1). 
ginning of Pan Tadeusz. There is no better place and time for understanding the 'homeland' as an emotional and conceptual whole, as the territory and time of emigration. It is the destiny of human consciousness - only being isolated from concrete reality, being outside of a certain process, it is capable of seizing it in wholeness. 'Minerva's owl flies out at midnight', Hegel said, 'which means that only the past can be truly understood'. But, unlike the river, which, according to the dictum of another famous philosopher, you cannot enter twice, the homeland, as the past of an emigrant, creates his present, his desired future.

Emigration is an ideal situation for the 'assembling' of one's own life project and ego-concept within the national narrative. The Fatherland remained, at least temporarily, behind the shoulders of the emigrant, turning from his 'now' of emigration, he can cover with a single glance both the whole of its history and the whole of his own biography. This whole national history and his own life 'at home' are subject to common awareness: they need to find a common meaning and evaluation. The emigration trauma 'I am not at home' is reflected in the emigration consciousness by a kind of phenomenology of the Fatherland: the homeland now exists except for me, and this lack has its reasons - it (the homeland) has removed me, I have removed myself from its space, due to certain historical, social, political reasons, because of the lack of necessary conditions in it. The elimination of this shortfall will be the moment of my real return to my homeland, or perhaps my return will contribute to this elimination. That is: the consciousness of the emigrant is not only open to the emotional and semantic-complete comprehension of the national narrative, but also contains, as a rule, this narrative in the eschatological or messianic horizon ${ }^{13}$. Let us transfer these general considerations to concrete ground. The Belarusians had to go to Prague for higher education, because at home, in Western Belarus, there were no corresponding centres of Belarusian higher education, the system of social elevators did not work properly, and the crystallization of the institutions of national culture was forcibly stopped by political obstacles. Accordingly, modern Belarus was interpreted by them as deprived of the highest culture by means of violence, as a space of social and national inequality, and they saw their return as an omen of the return of justice and culture to Belarus. The words of one of the characters of Born under Saturn Tamaševič (real prototype Tamaš Hryb):

На нашай Бацькаўшчыне, паўтараю, зараз зіма. Не адзін і не два чалавекі выходзяць на дарогу і глядзяць, куды паварочваецца сонца, калі ж прыйдзе, нарэшце, сапраўдны

13 It should be noted that elements of such 'emigrant' phenomenology of the Fatherland in the 1920 s were inherent not only in the Belarusian diaspora, but, at least partially, in all circles of the Belarusian national intelligentsia. Even residents of Minsk or Vilnius felt after the Riga peace 'not at home', as its substantial part was on the other side of the border, almost in another world, on the other side of the accessible, visible. Therefore, even the nationally oriented intellectuals directly present on the territory of Belarus saw its whole in the same eschatological, messianic horizon, as the desired future, as the return of the lost, 'taken from them'. 
дзень, калі засмяецца, зазелянее радасна зямля, калі прыляцяць ластаўкі - першыя весніцы вясны..

Мы ўсе 3 вамі - гэтыя ластаўкі, грамадзяне; мы панясём культуру, уласную культуру ў свае родныя хаты. I што тады будзе, глядзіце, калі мы ўсе, далучыўшыся да сучаснай еўрапейскай культуры, з’явімся цэлай грамадой на родных палёх. Сапраўды, грамадзяне, будзе нешта новае ў гісторыi! ${ }^{14}$ (Val'tar, 2009, p. 134).

The fact that Tamaševič's speech is close enough as in its content, so as in the total pathos and therhetorical means, used to the speech actually by Tamaš Hryb - the prototype of the hero Born under Saturn, can be seen by comparing it with the subsequent text by Tamaš Hryb: 'недалёка ўжо той час, калі беларуская народная інтэлігенцыя як суспольная група, як канструкцыйна-творскі чыннік ў жыцці працоўнага суспольства ўстане фактам жыватворчасці [...] распачнецца новая бачынка ў гісторыі Беларусі!'15 (Gryb, 2017, p. 99), see also a characteristic use of the metaphor 'першыя ластаўкі'16 - the messengers of spring (Gryb, 2017, p. 99; H-be, 1919, p. 1).

In this small passage all the elements of the mechanism of semantic-emotional construction of 'homeland' are concentrated, traces of which are repeatedly found in Born under Saturn and which, perhaps, should be considered as peculiar to the Belarusian students in Prague (no wonder the words are put into the mouth of the character, who had a real prototype).

1) It is winter in our Homeland. Firstly, it is a reactualization of one of the most extended and characteristic for the Belarusian national movement of the beginning of the $20^{\text {th }}$ century tropes: its own higher culture as 'the sun', which Belarus, frozen in the northern winds of history, is waiting for. This trope appeals to the agricultural imagination, to the cyclic sense of the universe, traditional for the sower, and mobilizes the semantics of Enlightenment with its characteristic correspondence mind = light. This Homeland is like the time of winter, it is, secondly, the comprehension of temporarily abandoned Belarus as insufficiencies - not only Belarusian students are homesick, but the Homeland itself is incomplete without their children, their emigration is temporary, and their coming back will be as the return of Belarus to its essence, the remigration of the most expected and cherished. Thirdly, 'winter at home' has another implicitly semantic pole - now Belarus is a space of suffering and death, to which they return for

14 'In our Homeland, I repeat, it is winter. Not one or two people go out on the road and look where the sun turns, when the real day finally comes, when the earth laughs, turns green with joy, when the swallows arrive - the first messengers of spring... We are all with you - these swallows, citizens; we will carry culture, our own culture to their homes. And what will happen then, look, if we all, joining the modern European culture, appear as a whole community in their native fields. Indeed, citizens, there will be something new in history!'

15 'the time when the Belarusian national intelligentsia as a social group, as a structural constructive element in the life of the working community will become a fact of creativity is approaching [...] a new page in the history of Belarus will begin!'.

16 'first swallows'. 
heroic deeds, looking for a heroic death in the name of the ideals of the future. Homecoming as selfless death is a hidden biblical motive that explodes semantically at the final parts of the novel.

2) Not one or two people go out on the road and look - it is a kind of 'montage' of several conceptual and emotional matrices. Firstly, those who 'go out and look at the road' are the parents, relatives of students. They are especially longing for the return of their sons and daughters, hoping for the reunification of the orphaned family, for their help in the economy. In this emotional frame Tamaševič offers Belarusian students to comprehend their return to Belarus. The Fatherland, baćkaǔščyna, is a big family, one community, connected by blood ties. Secondly, again, the expectation of Belarus for its own intelligentsia correlates with the outlook of the traditional sower: as the farmer greedily catches the first signs of spring, exhausted by winter gloom, so Belarusians are waiting for their national intelligentsia. Thirdly, we see a characteristic technique of multiplication of a single sensory experience on the whole territory of Belarus: parents, farmers are waiting, missing - one, 'two people', and - so throughout Belarus. This 'prototype' is not a single emotion, social and life situations are transferred to all the apparent whole of Belarus, which is also very characteristic of the construction of 'Fatherland' in the novel.

3) We are all with you - these swallows - the audience of Tamaševič's listeners, the audience of the Belarusian students of Prague performatively unites into the following communities, as is announced by them:

a) the only 'emotional community' ${ }^{17}$ : - a community bonded by unity, or at least by similarity of emotional states and reactions: a community of those who are equally homesick, who even outside it comprehend themselves, see themselves connected with the fate of Belarus. Those who equally hope to come back to Belarus, and who see their return as a step of Belarus itself on the way back to its essence, the return of Belarus to the normative modernity of Europe. In a word, it is a community where everyone understands his own longing (for Homeland), hope (to return), pride (for the acquisition of education and dignity) as common characteristics for all Belarusian students, or Belarusian intelligentsia in general, and at the same time, projecting them all over Belarus as apparent subjectivity: Belarus misses its swallows - intellectuals, trust them and proud of them.

b) the community fuel of the national narrative: it is the fate and actions of the Belarusian students of Prague that determine the historicity of Belarus at the current moment ${ }^{18}$. The completion of the actual stage of the history of Belarus as a state of

17 The concept was introduced into scientific circulation by Barbara Rosenwein, who tried to present in her monograph in 2006 the history of the early Middle Ages as a history of relationships and competition between several similar communities. Rosenwein defines 'emotional communities' as 'groups in which people adhere to the same norms of emotional expression and value - or devalue - the same or related emotions' (Rosenwein, 2006, p. 2).

18 In these passages we do not express our own opinion, but only reveal the hidden meanings of the statements of the characters of the novel. 
absence of higher culture, statehood, subjectivity, the denouement of its current tragedy - all this is connected with the process, the carrier of which Prague students must realize themselves. The trajectory of the Belarusian history is emphasized in mental and geographical space: Belarus lacks modern European culture, it must return to the European family from its temporary, occasional, 'past'. And who, if not Belarusians, who are already in the center of modern Europeanism, are to be agents of this transfer - as if Tamaševič seems to ask.

4) We will carry culture, our own culture, to our homes. If you look closely, the phrase is woven of paradoxes.

First of all, is it possible to 'carry' or 'bring' culture? Would not such an action be like carrying water in a sieve? Or - trying to collect the evening rays at sunset to turn them into dawn in the East? Does not every local culture have its own rhythm and pace of development, and do you first need to mature in order to recognize in the 'brought' 'own'? Otherwise, the 'carrier' of culture risks becoming a much less solid figure - the owner in the Chinese parable, who pulled the rice sprouts to make them grow faster? Who has the right and the necessary foresight to determine what the development of culture will be and what future it will unquestioningly recognize as its own? In addition, besides this 'vertical' problem, the idea of 'carrying' culture has got questionable semantics in the 'horizontal' plane. Culture is not an easy object to 'export' - its artifacts do not lose their national identity when transferred across the state border, and, for example, literature remains 'Belarusian' or 'Czech' even when translated into another language. If we are talking about science and knowledge, they, on the contrary, resist 'nationalization', attempts at appropriation, and we can speak of them as 'own', Belarusian, only in a figurative sense. How is it possible to bring something that is already 'own'? If we understand this 'bringing' of one's own as something that changes the very essence of 'one's own', as a change of the 'owner' - Belarusian culture - then, will there not be a danger of destroying the identity of 'one's own', and its original way of development will be missed when returning to Belarus with cultural 'gifts'?

Secondly, who are the 'we' who are destined to carry 'our own' culture to 'our' homes? The students of Prague? The Belarusian intelligentsia? Does this mean that the Belarusian student of Prague should be the final arbiter in the questions: what culture to recognize as 'own' and what (who) really belongs to the circle of 'their' homes? How is it possible to smooth already visible difference in the views of the Belarusian community in Czechoslovakia? How can 'we' be transformed from a mere grammatical convention into the name of genuine unity? By consensus, negotiations among the various parties, or by the expulsion beyond the field of 'Belarusianness' of other views? Or vice versa - the concept 'we' is defined through belonging, obedience to 'our homes' and 'native fields'? Does it mean: appropriate - peasant - social origin and relevant to his outlook? Thus, not all those present are invited to Tamaševič's 'we', it does not so much unite all Belarusian students into a single community, but, on the contrary, excludes the circle of the chosen among them, and, paradoxically, the semantic emphasis in 'we' falls on 'no-we'. 
5) There will be something new in history! - at the end of Tamaševič's statement, an eschatological message is manifested: after joining the modern European culture, an unknown for Tamaševič and the Belarusian student community begins, the history of Belarus as a visible and understandable whole breaks off, ends, and then 'something new', uncertain and unpredictable takes over.

No wonder, practically in two pages of the text and at the same meeting of the Belarusian students of Prague, where Tamaševič's words rang out, a scandal erupted: Tuhoŭski provokes his personal enemy Zahorski, accusing him of a nobleman's manor origin, namely that 'mother's milk', that the baby Zahorski drank, is not of good quality: 'дваранска-памешчычым сынкам не мейсца ў нашай сям'i' 19 (Val'tar, 2009, p.136), because 'толькі з малаком маткі ўвальецца ў кроў свядомасць тых, хто пойдзе за лапцюжную Беларусь ${ }^{20}$ (Val'tar, 2009, p. 135). At the same time, with the same words Tuhoŭski makes a compliment to his beloved Heliena Viarchoŭskaja, meaning: she will become such a 'conscious' mother, she will be able to bring up real Belarusians. As a result, Zahorski is forced to object to the use of the pronoun 'we' by Tamaševič and the community of fate and views outlined by him: 'Тут Тамашэвіч клікаў нас кудысьці, як той чыжык у казцы Максіма Горкага. Але я ведаю, грамадзяне, што ёсць вышэйшыя культуры, да якіх імкнуцца маладыя народы’21 (Val'tar, 2009, p. 136). After his friend - Šabunievski - has been kicked out of the party, Kiryl Buračeǔski, the host of the party at which the events take place, says: 'Скандал ускрыў цёмны бок нашага грамадскага жыцця: уласне, прысутнасць чужых, шкодных нам элементаў. Ім мейсца сапраўды, як казаў сябра Тугоўскі, у расейскім камітэце. Дзеля гэтага я па-сяброўску папрашу іх пакінуць мой пакой'22 (Val'tar, 2009, p. 136). Belarus - as a single family, connected by blood relations; 'We' of the Belarusian intelligentsia seem to be connected by the unity of views and social origin; confusion of the personal past and the desired cultural future - all these semantic paradoxes explode with corresponding events in the plot ${ }^{23}$. And, as we see, the main character of the novel uses the hidden conflict, emotional fuse of these definitions not at all for the sake of joint, social purposes, but solves with their help his own, personal tasks.

19 'noble-landlord sons have no place in our family'.

20 'only mother's milk will flow into the blood the consciousness of those who will follow bast-shoe Belarus'.

21 'Here Tamaševič called us somewhere, like that Siskin bird in Maksim Gor'kii's fairy tale. But I know, citizens, that there are higher cultures which young people strive for'.

22 'The scandal has revealed the dark side of our social life: namely, the presence of foreign, harmful elements. Their place is really, as friend Turovskii said, in the Russian Committee. For this I will kindly ask them to leave my room'.

23 The fact that such intensity of relations between students, and such disputes around the Belarusian identity, as well as the identity of the 'Belarusian intellectual' is not a work of the artistic imagination of $\mathrm{V}$. Valtar can be seen by reading the reports of the representatives of the Czechoslovak Interior Ministry, who attended all the main, official meetings and events of the Belarusian student communities (Buča, 2012, pp. 297-310). 
However, such behaviour by Tuhŭski is also explained by the same semantically-emotional unit, in which the concept of 'baćkoǔščyna' from Tamaševič's speech arises: the vision of his own 'I', the designing of his personal life trajectory and national narrative, and eschatological Belarusian history are so densely confused in it, that it is not surprising that it confuses his own feelings and desires with imagining himself in as a social agent ('sincere Belarusian'), and starts to interpret the decision of personal vital tasks as absolutely necessary for Belarus actions. Tuhoŭski thinks: 'ён усё ж ткі хоча мець асабістага шчасця толькі ў такой меры, каб мець цвёрды грунт для змагання за шчасце ўсіх, за шчасце цэлага народу. А гэтае жаданне не такое ўжо вялікае: толькі б яго пакахала Вярхоўская. Яму здавалася, тады ён паверыў бы ў сваю вартасць, тады быў бы шчаслівы - і тады мог бы стаць сябрам Грамады ${ }^{24}$ (Val'tar, 2009, p. 175). These, at first glance, absurd or, at least, youthfully unreasonable thoughts have their logic in the categories through which Tuhoǔski understands life. He does not see himself as an individual, a person - in his own eyes he is a 'swallow', a character of the national eschatological narrative, one who is destined to bring happiness to all people. And in such a narrative logic, it would seem that the 'swallow' also should have its own grain of happiness.

Throughout the novel Tuhoǔski, in fact, runs from his own individuality, like that particularity, which is not defined by anything except chance; runs from interpersonal relationships, which are built on the 'law' of personal preferences, and not on social or traditional prescriptions; runs from the abyss of his own freedom. Every time he looks for a certain set, where he can fully include the individuality of his 'I', count and calculate it, look at it as a simple realization of general laws: even if it will be 'born under Saturn', whose life from beginning to end is formed of misfortunes, because so decided the stars; or 'sparrows' - people who are destined to obedience, a secondary role in society, because of some initial flaw in the structure of their brain (Val'tar, 2009, p. 120), but not only an unacceptable existence, whose fate is decided every minute anew. The tragedy of Tuhoŭski is the tragedy of the first generation of the Belarusian intelligentsia, the embodiment of the gravity of becoming oneself, after separation from the umbilical cord of traditional society.

'Але што такое чэснасць, айцец, што такое чэснасць? Ты жа яшчэ марксіст, - акідваў Малевіч Кірылу вокам пераможцы.

- Чэснасць быць самім сабой, сябра Малевіч 25 (Val'tar, 2009, p. 152) - read in Born under Saturn.

Malievič is one of the carriers of the 'bourgeois' worldview in the novel, who is looking for marriage with a rich Czech woman, an ordinary career, and simple,

24 'he still wants to have personal happiness only to such an extent that he has a solid ground for fighting for the happiness of all, for the happiness of the whole people. And this desire is not so great, if only Viarchoŭskaja would love him. It seemed to him that then he would believe in his worth, that then he would be happy - and then he could become a member of Society'.

25 "'But what is honesty, father, what is honesty? You're still a Marxist," - Malevich looked Kiryl over with a victorious eye. - Honesty to be yourself, friend Malievič'. 
unambiguous truths of the 'technical' sciences (to him belong the following words: 'філасофія ёсць навука аб ні для кога не абавязковых ісцінах'26 (Val'tar, 2009, p. 127). He asks 'father' Kiryl 'what is honesty?', imposing on him, as a social role, as once and for all established his worldview, Marxism. He receives Kiryl's answer on that: 'Be yourself' It is NOT difficult to notice: we have a 'secular' retelling of the biblical story. 'What is truth?' - Pilate asked, standing before the embodiment of Truth, before the personified Truth. 'What is honesty?'- asks Malievič, meaning: honesty, like truth for Pilate, is relative, transient, and therefore we are deprived of responsibility. 'But not in front of myself' - so, in fact, was Kiryl Buračeǔski's answer to him. The same dialogue will be repeated in the soul of Tuhoŭski, a dozen pages later. But, unlike Buračeŭski, for Tuhoŭski this internal dialogue will end with defeat. Tuhoŭski is outraged by the smug lecture of the Professor of political economy, who shames socialist teachings and extols capitalist economy, and this will be the occasion for such a monologue:

Як жа ён зможа вучыць тое, чаму ён сам не верыць, і як ён пойдзе на экзамен да гэтага залатазубага прафесара, якога ён ненавідзіць усёй сваёй душой? Што ён будзе адказваць яму? Тое, што казаў прафесар, - проста зазубрыўшы адказы, як папугай? Не, ён гэтага не мог бы зрабіць. Ён не пойдзе проиіў голасу свайго ўласнага сумлення.

Перш за уусё трэба заставация чэсным з самім сабой. Тады спрачацца з прафесарам, даказваць яму, што ён памыляецца? Але... Ён яшчэ досыць слабы, можа быць, пасля такой дыскусіі прафесар выправіць яго 3 кабінету як за незадавальняючы адказ... Значыць, так ці інакш, выхаду няма ${ }^{27}$ (Val'tar, 2009, p 166, the italics are mine - I.N.).

In order not to give the impression that our conclusions are based solely on a small passage, on the words of a single character from Born under Saturn, we shall give a few more illustrations.

Let's start with the most provocative thesis. We propose to interpret the metaphor 'Belarus as a space of winter domination' in the following way: return to the homeland $=$ death and $/$ or immortality.

It is on this trope that the end of the novel is built: Tuhoŭski, who decided to shed his own and others' blood 'на алтар Бацькаўшчыны' ${ }^{28}$ (Val'tar, 2009, p. 245), will get lost, lose his way and die somewhere in the Carpathians on the Czech-Polish border.

26 'philosophy is the science of non-obligatory truths for anyone'.

27 'How can he teach what he does not believe in, and how will he go to the examination of this gold-toothed Professor, whom he hates with all his heart? What would he say to him? What the Professor was saying - just memorizing the answers like a parrot? No, he couldn't do that. He will not go against the voice of his own conscience.

First of all, you need to be honest with yourself. Then argue with the Professor, to prove to him that he's wrong? But... He is still quite weak, maybe after such a discussion the Professor will expel him from the office as for an unsatisfactory answer... Means, so or otherwise, there is no exit'.

28 'on the altar of the Fatherland'. 
In a moment, when he decided to to return, he already predestined in his own eyes his rapid death. Only one question remained: will he be able to achieve human attention and memory by his death, to return 'on the shield'.

'Вяртанне на бацькаўшчыну азначае для Тугоўскага нішто іншае, як спосаб самагубства - аднак самагубства 3 прысмакам самаахвяравання' ${ }^{29}$ (Ščur, 2011, p. 615). Tuhoŭski's own words: 'Ну дапусцім, што страляць у іншых, каб потым быць самому расстрэляным, ёсць асаблівы від самагубства. Я выбраў сабе гэты від самагубства, бо лепшага не знайшоў, i ўсё’30 (Val'tar, 2009, p. 257).

$\mathrm{He}$ had cast lots in a game in which posthumous fame was at stake. The author will have mercy and give him the last chance - the last defeat of life, which will be the victory of his theory, the victory of Tuhouski-philosopher. The insignificance of Tuhouski's death seems to become the last argument in favour of the rightness of his philosophical 'tractate': Споведзь самагубиьл. Кніга для уссіх і ні для кога ${ }^{31}$ (Val'tar, 2009, p. 119-122; 259-260) $)^{32}$. No wonder that this text, with which the reader is acquainted at the beginning of the novel, is also at its completion. Valtar puts the final, decisive point in the philosophical manifesto of Tuhoŭski, - a point which he, Tuhoŭski could not find. Only our mortality is not subject to chance, inevitable for a human being. Only in people's memories we shall remain forever as heroes or losers. Alive, or even forcibly and with his own hand cut off his life, Tuhoŭski could not become the embodiment of his theory: according to which he belongs to the state of congenital failures. Only about the deceased it could be said that he was not given to taste happiness in life. The plot of the novel each time refutes Tugoŭski when he brings a negative account of his life - not receiving a scholarship from the Czechoslovak government, and has strengthened his ego-concept as a priori unfortunate astrological arguments of an 'astral man', he writes

29 'Return to the homeland means nothing but a way of suicide for Tuhouski - but suicide with a touch of self-sacrifice'.

30 'Well, let's say that shooting at others, then to be shot himself, is a special kind of suicide. I chose this kind of suicide, because I could not find a better one, and that's all'.

31 'The Confession of a Suicide. A Book for All And for None'.

32 As is well known, the academic career of Tomas Garrigue Masaryk - the 'father' of the Czechoslovak nation, the first and acting at the time of writing the novel the President of Czechoslovakia, began with the habilitation work Der Selbstmord als soziale Massenerscheinung der Gegenwart (Suicide as a Mass Social Phenomenon of Our Time). In it Masaryk tried to analyse suicide as a social phenomenon, and came to the conclusion: for modern times peculiar to a kind of 'attack' of suicides, due first, the separation from religion and faith in God, a break with traditional morality, and secondly, mass, but half-education - a large number of the population receives basic knowledge, and accordingly - the ability to pose existential questions, to observe and comprehend their inner life, but, as a rule, does not acquire in the school specific goals for life, those humanistic ideals that could be the real purpose and justification of their existence (see Masaryk, 1926; Kilias, 2013, pp. 95-96). In, both Tuhoŭski's 'tractate'and Valtar's novel itself became a kind of 'amaž' (a kind of interest, thanks for inspiration) to this text by Masaryk (it is almost impossible that Valtar did not hear about this work during his studies in Prague), an existential answer to the problems raised by the Czech President-philosopher. 
the text of the Confession, prepared for suicide, but he is held up by Kiryl Buračeŭski, who brings him news about scholarships finally given to him and about the arrival in Prague of Haliena Viarhoǔskaja who will become his love, and his way of returning to life (Val'tar, 2009, pp. 122-125); after an unsuccessful experience of 'simplifying', again completely disappointed in life Tuhoŭski returns to the idea of suicide and to the text of the Confession, but accidentally meets Viarchoŭskaja and learns that the community of Belarusian students is seeking him, that he is needed by the Belarusian society and he will again be assigned a scholarship (Val'tar, 2009, p. 226-227). Every time he wants to be convinced of his imaginary illness, the doctors disappoint him: he has no syphilis (Val'tar, 2009, p. 211; 239). Tuhoŭski, in vain, is looking for in his past an irrefutable evidence of the theory of 'sparrows'. His attempts to plug by philosophical reasoning that gap of being as it is, in vain, and only entering into an unfamiliar future, giving himself to the mercy of chance / $\mathrm{God}^{33}$, he will receive the desired confirmation. Only the author of the text can make his character unconditionally unhappy, and in reality, outside the fictitious world - only chance / God and human memory - this, perhaps, should be the final philosophical outcome of Born under Saturn.

But we are interested in another point: that Tuhoŭski perceives his return to Belarus as a step into a radical future. To cross the Polish-Czech border for him means to cross the line that separates the past of Belarus, as well as his own past, from the eschatological future. If Tuhoŭski just returned home not as a prospective terrorist, but an ordinary man for a simple life, it would be according to his worldview, as per the opinion of students of Prague, only ersatz suicide, - is not back, but escape from the real native land:

Я хачу апрасціцца... Я памёр для тых, хто прывёў мяне ў Прагу, каб я вяртаўся назад прафесарам ${ }^{34}$ (Val'tar, 2009, p. 196);

Я? - усміхнуўся Тугоўскі. - Як бачыш, яшчэ боўтаюся ў Празе, хоць збіраўся ехаць на Бацькаўшчыну ў якую-небудзь палескую глуш, далей ад праклятай культуры... Хоць да эскімосаў якіх-небудзь на паўночны полюс, толькі б далей ад гэтых подлых масак, якія называюць сябе людзьмі ${ }^{35}$ (Val'tar, 2009, p. 221).

In Belarus, in which the heroes of Born under Saturn are going to return, 'there is always a place for a feat', but there is no place for ordinary life.

Before Tuhoŭski makes the final decision to return to his homeland as a terrorist, we find in the text a fragment with a confused personal attribution - before us, whether the thoughts of Tuhouski himself, filed in the form of double indirect discourse, or the words of the impersonal narrator of Born under Saturn. This is a fragment in which

33 Let us leave the choice to the reader of the novel.

34 'I want to simplify... I died for those who brought me to Prague to come back as a Professor'.

35 'I? - smiled Tuhouski. “As you can see, I'm still hanging out in Prague, although I was going to go home to some Polesie wilderness, away from the accursed culture... At least to the Eskimos somehow to the North Pole, if only away from these vile masks that call themselves people"' (Val'tar, 2009, p. 221). 
the latest events in Belarus are set out in the narrative frame of Tamaševič's speech: 'гінулі ластаўкі, захопленыя зімой на Бацькаўшчыне' ${ }^{36}$ - young students, lured from cosy Prague by the light of the ideals of social equality and national liberation, die 'у турэмных халатах на дошках' ${ }^{37}$ (Val'tar, 2009, p. 235). The interwar Polish state, of course, was not a model of democracy and its national policy could attract a lot of claims, but to say that inevitable death awaited for the Belarusian students on their return from Czechoslovakia is an evident exaggeration. The logic of this 'apocalyptic' vision, in our opinion, is set by the narrative frame of 'swallows and winter'. Belarusian young men returned to their homeland not as individuals, with a wide open outlook on life, but as messengers of an unknown future. Only there, in the future, in the world of free Belarus and free Belarusian people, they can really return to their particular, private life, meanwhile the only alternative is: either die for the Fatherland, or die in the eyes of the Belarusian society, disappear from the prospects of historical memory. The two main 'losers' of the novel - Tuhoŭski and 'father' Kiryl comprehend their life defeat in the perspective of the Belarusian future, which will never know their names and will not write their names in the pantheon of national heroes:

Я хацеў бы, каб мяне пахавалі на высокім беразе Нёмана, каб заўсёды быў бачны камень, каля якога бурліць яго сярдзітае цячэнне, каб у часы сваіх разліваў ён абмываў мае косці, як абмываў цела дзіцяці, калі я купаўся ў ім у залацістыя сонечныя дні маёй вясны. I яшчэ хацеў бы я, каб на гэтым камяні былі высечаны словы аб памёршай ластаўцы, што не дачакалася вясны на беларускіх палёх... ${ }^{38}$ (Valtar, 2009, p. 220);

Калі ў велізарнай храміне, на франтоне якой літарамі будзе напісана „Вольная Беларусь”, запаляць свечкі на ахвярніку - напэўна, ні адна свечка не запаліцца за яго, невядомага Тугоўскага, невядомую ахвяру цемры. Ну што ж... Няхай даруе яму Бацькаўшчына за тое, што ён не зрабіў для яе. „За кроў яго, агульную з народам, даруй, о родны край, даруй..."39 (Val'tar, 2009, p. 258).

The life of the Belarusian intellectual passed as if under the 'supervision' of future generations: it was possible to give sense to own life only having checked the status of the national hero. The 'design' of the existence of the Belarusian intellectual

36 'swallows captured in the winter at home died'.

37 'in prison gowns on boards'.

38 'I would like to be buried on the high bank of the Neman, so it could always be seen the stone beside which its angry current swirls, so it could wash my bones in its hours of inundation, as it washed the body of the child when I bathed in it in the golden sunny days of my spring. And I would also like to have the words about the dead swallow, which did not wait for spring in the Belarusian fields, carved on this stone...'

39 'If candles are lit on the altar in a huge temple, on the facade of which "Free Belarus" will be written in letters, probably not a single candle will be lit for him, the unknown Tuhouski, the unknown victim of darkness. Well... Let the Fatherland forgive him for what he had not done for it. For his blood, common with people, forgive, o, native land, forgive...'. 
was distinguished by a specific shift of the ego-center: just as Tuhouski 'згубіў ужо тую непасрэднасць пачуццяў, тую жывасць адчуванняў, якая бывае ў жывога, зацікаўленага жыццём чалавека; другімі словамі, ён глядзеў на жыццё, як даследчык глядзіць на марскую свінку'40 (Val'tar, 2009, p. 125), and the national intelligentsia looked at itself with an alienated 'look from the future' - nothing makes sense and is worth attention until it receives a sanction from tomorrow's free Belarus. A living person can receive such sanction only in advance: as long as his earthly stay lasts, his characterization as a hero is always in question, and only death can put the final full stop in his narrative.

Also important is the rationalization of the victims of the younger generation, which we find in Born under Saturn:

Беларускі рух не стаў настолькі шырокім і моцным, каб з ім лічыліся, як з вялікім культурным з'явішчам. Яшчэ трэба несці шмат мук, трэба праліць нямала крыві, каб нарэшце рух стаў не толькі „крамолай”, не толькі „бунтам” незадаволеных галодных мас, але каб ён стаў моцным і глыбокім, як само жыццё, як патрэба жыць і дыхаць, каб ён атрымаў усясветную сімпатыю.

Толькі кроў, гэта неўміручае каханне, можа выклікаць сімпатыю людзей; толькі ахвяры могуць прыняць вянок перамогі, і толькі жывыя людскія ахвяры могуць прымусіць схіліць галаву самых заўзятых ворагаў. Болей ахвяр! I яны неслі ахвяры, гэтыя маладыя беларускія рыцары, гэтыя бяздумныя гладыятары, не шкадаваўшыя свайго жыцця. Яны гінулі ў турмах і ўміралі ў турэмных шпіталях як арыштанты ${ }^{41}$ (Val'tar, 2009, p. 234-235).

The paradoxical formula: to give life to the Belarusian movement just through giving up life, sacrificing one's life, finds its explanation in the words 'immortal love' ${ }^{42}-$

40 'has already lost that spontaneity of feelings, that vividness of feelings that happens in a living person, interested in life; in other words, he looked at life as a researcher looks at a Guinea pig'.

41 The Belarusian movement has not become so broad and strong that it was considered as a great cultural phenomenon. There is still much suffering to be endured, much blood to be shed, so that at last the movement becomes not only a 'sedition', not only a 'revolt' of the discontented hungry masses, but it becomes strong and deep, like life itself, like the need to live and breathe, so that it receives universal sympathy.

Only blood, that immortal love, can arouse the sympathy of people; only sacrifices can take the crown of victory, and only living human sacrifices can make the most ardent enemies bow their heads. More victims! And they made sacrifices, these young Belarusian knights, these thoughtless gladiators who did not spare their lives. They died in prisons and died in prison hospitals as prisoners.

42 The text of the novel shows that Valtar confuses the words 'любоў' і 'каханне' ('love' and 'passion'), and does not follow the distinction of their semantics accepted in the modern literary language. See e.g. 'Nationwide love' (Val'tar, 2009, p. 124); 'Love of alcohol' (Val'tar, 2009, p.130); 'I love him, a man humiliated and insulted' (Val'tar, 2009, p. 194). We are therefore inclined to understand Valtar's 'passion' in this passage as 'love'. 
only love, that will become death for its bearer, is worthy of the name 'immortal', only it does not threaten to change, wither and disappear under the weight of life circumstances, only it does not depend on the 'пад вечар, як казаў адзін філосаф, няможна было выкупацца ў той самай рацэ, у якой купаўся зрання’43 (Val'tar, 2009, p. 234). The way out of Heraclitus's modernity, which every minute disputes, 'washes away' ideals, in a prosperous future of free and fair Belarus is seen as possible only through death. Very characteristic from this point of view is Tuhouski's monologue, voiced by him at a time when he thought he was sick with syphilis: 'Як трагічна... Загінуў не ў імя вялікіх ідэй, дзе-небудзь у турме, у барацьбе, як тыя героі беларусы, аб якіх несліся чуткі з Бацькаўшчыны, а як брудны чарвяк у памыйнай яме жыцця. Ах, смейся, паяц, над каханнем Тугоўскага!'44 (Val'tar, 2009, p. 240). Tuhoŭski, as we can see, is characterized by alienation from his own life - he does not live it, but all the time weighs it 'on the scales' of assessment of future generations of Belarusians. He does not see his own being as his own, but only as a tragedy, or an object for the laughter of the 'clown'. Existence itself, not sanctified by great ideas, is to him like the stirring of a 'dirty worm in a cesspool'.

Our thesis: the desired and expected future of Belarus - a free European country of justice - was not so much a real aim-aspiration of the Belarusian intellectuals of Prague, as an eschatological framework for their auto-narrative, the border beyond which the unknown and the uncharted began, can be illustrated by the following words of Buračeŭski and Tuhoŭski:

Мы хочам, каб запахла мёдам, каб сонца заглянула, нарэшце, у шырокае вакно новай сялянскай хаты; „калі-небудзь, калі будучыя пакаленні выйдуць у белай вопратцы з сцягамі і штандарамі вітаць новае жыццё вольнай і братэрскай сям'ёй, калі ў велізарнай храміне, на франтоне якой літарамі будзе напісана „Вольная Беларусь” 45 (Val'tar, 2009, p. 170; 258).

There are no specifics - when and in what social forms the dreams of the heroes of Born under Saturn will come true, there are only quasi-perceptual (the smell of honey and white clothes) metaphors associated with archaic, fabulous connotations.

43 'river of time', when, as one philosopher said, it was impossible to bathe in the very river in which he bathed in the morning.

44 'How tragic... I died not in the name of great ideas, somewhere in prison, in the struggle, like those heroic Belarusians, about whom rumours were carried from the Homeland, but as a dirty worm in the cesspool of life. Oh, laugh, Pagliacci, over Tuhoŭski's love!'.

45 'We want the smell of honey, so that the sun finally looked through the wide window of the new peasant hut'; 'Someday, when future generations will come out in white clothes with flags and banners to welcome the new life of a free and brotherly family, when in a huge temple, on the facade of which in letters it will be written "Free Belarus". 
What we have called 'prototyping', that is, the use of a single life experience, a specific perceptual frame as an emotional template for understanding the Fatherland, can be seen in the following lines from Born under Saturn:

Яму [Тугоўскаму - І.Н.] падалося, што ён бачыць асветленыя вокны, хату на далёкай Бацькаўшчыне, сваю старую матку за калаўротам, якая апавядала яму казкі. I раптам уся Беларусь 3 дымам печак, 3 пахам вячэры, 3 яе святамі, 3 п'янымі вечарынамі вырасла перад яго вачыма ${ }^{46}$ (Val'tar, 2009, p. 258).

The following passage is also remarkable, where, in addition to similar prototyping, we also find the transfer of our own feelings (longing and hope) to the object of the senses:

Ён [Тугоўскі- І.Н.] ведаў, што не толькі ён, але яшчэ чыесьці вочы сачылі за ім 3 Бацькаўшчыны. Ён ведаў, што чыесьці душы, як радыёхвалі, несліся ў начным прасторы і не давалі яму спаць усю ноч: то былі душы яго бацькоў. Ён ведаў, што яны аддалі ўсё, што мелі, каб яго вывучыць, каб працягнуць яго праз гімназію, каб мазолістай рукой стварыць яму лепшае жыццё, больш культурнае і прыгожае, чым тое, у якім яны самі жылі ${ }^{47}$ (Val'tar, 2009, p. 88).

We, of course, do not believe that the Prague students were thrown into the arms of bielaruščyna solely for reasons of semantic, existential or psychological order. In those who were Born under Saturn we find the proof of 'external', social reasons, which made the election of Belarusianness, return to Belarus the profitable life strategy.

First, to define oneself as a Belarusian meant to avoid the shameful stigma of 'emigrant': 'гэта быў інтэрнат для тых, што былі выкінуты за борт жыцця пасля вялікага рэвалюцыйнага землятрусу, для тых, якія згубілі “ўсё” і сталі “нічым”людскім пылам, гноем, заплямованыя ганебным словам “эмігрант”"48 (Val'tar, 2009, p. 93).

46 'He [Tuhoŭski - I. N.] thought he saw lighted windows, the house in a distant Homeland, his old mother at the spinning wheel, who told him fairy tales. And suddenly all Belarus with smoke of furnaces, with a dinner smell, with its holidays, with drunken parties grew before his eyes'.

47 'He [Tuhoŭsky - I. N.] knew that not only he, but someone else's eyes were watching him from the Fatherland. He knew that someone's souls, like radio waves, rushed through the night space and did not allow him to sleep all night: they were the souls of his parents. He knew that they had given everything they had to give him an education, to give him the opportunity to finish high school, to create a better life for him with a calloused hand, more cultured and beautiful than the one in which they themselves lived'.

48 'it was a hostel for those who were thrown overboard after the great revolutionary earthquake, for those who lost' everything 'and became nothing'- human dust, dung, stained with the shameful word 'emigrant'. 
Secondly, in a foreign language environment, among other cultures, the first impulse will be to look for their own kind, and, conversely, society is primarily prone to see in the emigrant his nationality - 'Russian', 'Belarusian'49 or 'Jew' - and only then a particular person. In the novel, we see how students are united by their nationalities on the benches of University classrooms (see: Val'tar, 2009, p. 163), as well as in pubs (see: Val'tar, 2009, p. 191). Here is how this feeling of alienation from the Prague townspeople, which indirectly pushed the Belarusian students to each other and to Belarusianness, is described by T. Hryb:

Беларуская эміграцыя, якая ў вагромістай большасці складаецца 3 студэнцтва, у найбольшым ліку сабраная ў Празе, адарваная ад родных палеткаў беларускай зямлі, пазбаўленая змогі непасрэдных стыкаў з беларускім народам, з беларускімі культурнаграмадскімі ўстановамі ды арганізацыямі ў Родным Краі, дзе бурлівай крыгай звінела жыццё, ды апынуўшыся ў культурна-псіхічнай атмасферы значна адрознай, чужой, непрыязлівай, дзе імя беларус выклікала здзіўленне, усмешку, пагарду ды толькі ў дзе-якіх колах спачуванне, разуменне, падтрыманне, стварала цягам некалькіх гадоў якісьці свет у сабе, мо абмежаваны, але свой, беларускі, захоўваючы свае асабістасці ды азнакі ${ }^{50}$ (Gryb, 2017, pp. 260-261).

Thirdly, it is necessary to take into account the fact that in interwar Prague to be a Belarusian meant the opportunity to hope for some financial support. We are referring to the 'Russian action' - the programme of the Prague government to support refugees from the former Russian Empire. In particular, expatriate students could count on financial assistance of 600 korunas, a set of free clothes and free tuition at universities in Czechoslovakia (Buča, 2012, p. 309). It should be emphasized: a) the aid was divided according to the principle of national identity - the money was given to 'Belarusian', 'Ukrainian', 'Russian', etc. students. That is, the division by nationality and engagement in national affairs had, among other things, the external economic source of its maintenance and renewal $\left.{ }^{51} ; b\right)$ as we can see both from the novel and from

49 It should be noted that in the questionnaires submitted by Belarusian students in Prague at the beginning of each semester, they could not only choose Belarusian as their native language and nationality, but even indicate their citizenship as 'Belarus'. Thus, in interwar Czechoslovakia, the BNR acquired at least such a half-phantom legitimization (Kolenovská, Plavec, 2017, p. 39).

50 'Belarusian emigration, which in the vast majority consists of students, mostly collected in Prague, divorced from the native fields of the Belarusian land, deprived of the possibility of direct contacts with the Belarusian people, Belarusian cultural and public institutions and organizations in their native lands, where the life rang by tinkling the ice floes, caught in the cultural and mental, vastly different, alien, hostile atmosphere, where the name Belarusian caused astonishment, smile, contempt and only in some circles there was sympathy, understanding and support, it has been creating, for several years, some kind of light in itself, maybe limited, but his own, Belarusian, preserving its features and signs'.

51 If you look more closely, the case looked much more complicated: 1) the Polish state questioned the status of immigrants given to students of Western Belarusian origin - according to the logic 
real historical sources, 'professional Belarusians', such as Mikalaj Viaršynin, Lieanard Zajac, Piotr Kračeǔski and Tamaš Hryb - ministers without a state, those who staked on the BNR and independent Belarus - applied for student scholarships to the Prague government. Their status in the Czechoslovak (Western European) society and career prospects directly depended on the increase in the circles of conscious youth, the 'creation' and renewal of bielaruskasśc, both in its human and 'textual' dimension.

A characteristic episode: during discussion of the return of a scholarship for Tuhoǔŭski (before these he has already refused it from ideological / personal reasons: disappointment in higher education, personified by the 'golden teeth' Professor, as an inability to achieve reciprocity from Viarchoŭskaja, temporarily pushed him on pseudo-Tolstoian path of 'simplifying'), Lieanard Zajac immediately tries to give him work in a journal: 'Вы маглі б зарабіць больш, чым на вашай цагельні, супрацоўнічаючы у 'Славянскай кнізе'. 'Славянская кніга' ' - бібліяграфічны часопіс на рускай мове, вельмі добра аплачвае працу. Я там маю беларускі аддзел. Збірайце бібліяграфічныя весткі і прыносьце да мяне ${ }^{52}$ (Val'tar, 2009, p. 232). As you can see, Belarusians of interwar Prague were also interested in the production of Belarusian culture financially.

These external, economic reasons attracted to bielaruščyna even completely random people, and a small circle of the Belarusian community in Prague was not able to refuse such random fellow travelers. So, at the beginning of the novel we meet such an episode:

Так... А ўсё ж дазвольце вас запытаць, пане старшыня [Старшыня Беларускай грамады ў Празе-Мікалай Вяршынін, Н.І.], - прамовіў юнак Тугоўскі з перакасіўшымся ад злосці тварам, з заблішчэўшымі вачыма. - Чаму вы прынялі на маё мейсца некалькі эмігрантаў з Балгарыі, такога Шабунеўскага, напрыклад... Ці ведама вам, што яны беларусы? І ці ведама вам, што яны не сёння, дык заўтра пяройдуць у расейскі камітэт?

Старшыня паморшчыўся і зноў палез на пасцель.

of the Polish government, it was not about refugees, but Polish citizens and the Czechoslovak government partially recognized the appropriateness of these arguments, reducing funding to 'Belarusians'; 2) And the Soviet state interfered in the relations between the Belarusians and the Czechoslovak government: ideological and financial support from the Embassy of the USSR was received by Pro-Soviet Belarusian students who counted on re-emigration to the BSSR (Buča, 2012, pp. 308-309). Thus, it cannot be said that in the economic field of interwar Czechoslovakia, the national Belarusian identity was for Belarusian students an unambiguous centre of attraction, the only rational and profitable strategy of behaviour. But: one or the other choice had to be made. In Prague, an expatriate student had to join a committee: 'Belarusians from Russian committees' (Val'tar, 2009, p. 135), or to the 'Soviet Belarusians' or to the 'sincere' conscious Belarusians. He had to join, enter the appropriate community, take on correlative ideas and discourses, an emotional regimen, behavioural practices and life strategies.

52 'You could earn more, than in your brickyard, cooperating in "The Slavic Book". "The Slavic Book" is a bibliographic journal in Russian, it pays very well. I have got a Belarusian section there. Collect bibliographic news and bring it to me'. 
- Ну ведаеце, грамадзянін Тугоўскі, гэта ўсё складаныя пытанні... Як бы вы зрабілі, калі б да вас прыехалі людзі з Балгарыі і заявілі вам, што яны беларусы. Такі Шабунеўскі сапраўдны беларус ${ }^{53}$ (Val'tar, 2009, p. 90).

Finally, fourth, in Prague, Belarusian students and emigrants were constantly confronted with communities of other nations of the former Russian Empire, who found themselves in a similar situation, and responded to it with similar narratives. Let us quote T. Hryb again. His vision of the emigrant students of Prague: " 3 аднаго боку расейцы - “адзіна-недзялімцы” - ды іх прыхільнікі, а з другога - “сепаратысты”беларусы, ды не адны, а з імі ўкраінцы, армяне, грузіны, горскія народы, урэшце кубанскія, данскія казакі ды іх прыхільнікі ${ }^{54}$ (Gryb, 2017, p. 261).

At the end of the novel we can observe the following situation: there is a public discussion of the 'national question in Russia' (Val'tar, 2009, p. 251) - next to and together with speakers from Belarusians, representatives of other nationalities speak, and they all speak in a uniform spirit. Here is how Valtar joins the speech of the Belarusian Kračeŭski (a), the speaker from the 'Caucasian highlanders' (b) and the Georgian representative (c):

a) На працягу сваёй гісторыі мы чулі на сабе цяжкую руку Масквы, знішчыўшую нашу культуру. А між тым, гэта культура была ў той час, як Масква пачыналася, і ў Полацку ўжо была гімназія, і з Полацку адпраўляліся маладыя людзі вучыцца за граніцу. Масква знішчыла ўсё, у 1859 годзе было забаронена друкаваць беларускія кнігі [...]

- Мы заяўляем, - закончыў Крэчэўскі, - што пакуль ёсць раб і пан, супольнай размовы і супрацоўніцтва быць не можа;

б) Мы, каўказскія горцы, заяўляем, што Расея нішчыла цэлыя плямёны горцаў [...] Але, грамадзяне, у нашых сэрцах яшчэ жывуць запаведзі вялікага Шаміля, іншых нашых правадыроў. Мы вымагаем, каб нам далі магчымасць збудаваць сваю саклю на скале, няхай недасканалую, але каб гэта была наша ўласная сакля;

в) Мы ніякая не Расея, ні Жоўтая Расея, ні Маларасея... Мы - Грузія, - казаў ён. У нас была высокая культура, нашыя грузінскія цары пасылалі сваіх жыхароў вучыцца

53 'Yeah... And yet let me ask you, Mr. Chairman [Chairman of the Belarusian society in Prague - Mikalaj Viaršynin, N. I.], - said the young man Tuhoǔski with a face twisted with anger, with sparkling eyes. - Why did you take to my place a few immigrants from Bulgaria, this Šabunieŭski, for example... How do you know that they are Belarusians? And do you know that they are not today, so tomorrow will go to the Russian Committee?...

The Chairman grimaced and climbed back onto the bed.

- You know, citizen Tuhoǔski, it's difficult questions... How would you do if people from Bulgaria came to you and told you that they were Belarusians. This Šabunieŭski is a real Belarusian'.

54 "On the one hand, the Russians - "the only indivisible" - and their supporters, and on the other - "separatists" - Belarusians, but not alone, but with them Ukrainians, Armenians, Georgians, mountain peoples, finally people from Kubań, Don Cossacks and their fans'. 
за граніцу, калі Масква была цёмнай вёскай. Што сталася цяпер з Грузіяй пасля доўгага панавання Рacei?55 (Val'tar, 2009, pp. 251-252).

The impression that was voiced after the event by Viarchoŭskaja: 'Гэта было нешта надзвычайна прыгожае па сваёй аднадумнасці. Падумаць, 23 аратары, усе, як адзін чалавек, заявілі: не хочам больш Pacei' ${ }^{\prime 56}$ (Val'tar, 2009, p. 253). This is obviously a characteristic reaction to such contact and harmony of national narratives in the Czechoslovak environment. Students of Prague saw that their claims and plans for the development of their own culture are normal and normative, they are not alone in them, so do other representatives of the former national satellites think and express themselves. In interwar Prague, the Belarusian community as an 'emotional community' by the very logic of its social location was included in a large 'emotional community' - representatives of the enslaved peoples of former Russia, with the basic homo-logical set of emotional matrices: fascination with folk culture and interest in national history, anger towards the Russian oppressors, dissatisfaction with the current situation and hopes for the future, as a time of return to independence and national principles. In this coherence of national narratives there was their strengthening and reinforcement, an exchange of 'building blocks' - mythologems and plot moves.

\section{Experience of history and corporeality as alienation}

In the previous section, we have repeatedly stressed that the main character of Born under Saturn Tuhouski is characterized by the alienation from his own being all the time he is in the weightless space of empty theorizing, tormented by the violent winds of his own sensuality and chance; instead of direct existence in his own life, he evades, runs away from it in external contemplation, tries in vain to weave it into the final verdict-narrative. The disintegration of Tuhoǔski's personality is reflected by this phrase: ‘А ўсё ж такі гняце мяне псіхалогія'57 (Val'tar, 2009, p. 159). Tuhoŭski does

55 a) 'Throughout our history, we have felt the heavy hand of Moscow, which destroyed our culture. And meanwhile, this culture was in the time when Moscow began, and there already was a gymnasium in Polack, and from Polack young people were sent to learn abroad. Moscow destroyed everything, in 1859 it was forbidden to print Belarusian books [...]

- We declare, - finished Kračeŭski, - that as long as there is a slave and a master, there can be no common conversation and cooperation';

b) 'We, the Caucasian highlanders, declare that Russia destroyed whole tribes of mountaineers [...] But, citizens, but the commandments of the great Shamil, of our other leaders, still live in our hearts. We need to be given the opportunity to build our saklya (mountain-dwellers' huts - note of the translator) on a rock, however imperfect, but that it be our own saklya';

c) 'We are not Russia, nor the Yellow Russia nor Malorussia... We are Georgia, - he said. - We had a high culture, our Georgian tsars sent their residents to study abroad, when Moscow was a dark village. What has happened now to Georgia after the long domination of Russia?'

56 'It was something extremely beautiful in its unanimity. To think, 23 speakers, all as one person, said: we do not want more Russia'.

57 'And yet psychology pursues me'. 
not talk about his life and phenomenological experience in terms of personality, but considers his own experiences in an abstract, alienated instance of 'psychology'. The phrase demands the question: who is the 'I' that psychology can burden?

Such an existential disposition, in our opinion, can be represented according to the text of the novel itself as a result of the double violence that the Belarusian intelligentsia of the first decades of the $20^{\text {th }}$ century endured - the violence of history and new anthropological knowledge. It was this double blow that knocked the experience of the self out of its integration into its own corporeality and historicity, made the search for 'great ideas' that could illuminate life, give it sense. Recent history (its brief summary we find in section IV of the first 'quadra' ${ }^{58}$, where it is presented as Tuhouski's memoir) in Born under Saturn appears as a completely external, violent instance, the element of surprise and unpredictability, beyond the study. History is not created - it breaks into a person's life, destroying his hopes and everything created by him:

I тут ударыў гром. Настала вайна ${ }^{59}$ (Val'tar, 2009, p. 112);

I вось - раптам рэвалюцыя. Асвяжаючая навальніца пранеслася ў паветры, шмат смелых сэрцаў запаліла смагай волі і святла ${ }^{60}$ (Val'tar, 2009, p. 113);

I раптам, нечакана, кінуўшы некалькі бронецягнікоў, пакінуўшы трупы на вуліцах, бальшавікі здалі Харкаў ${ }^{61}$ (Val'tar, 2009, p. 114);

Рэвалюцыя ўвайшла ў свае берагі... Рэвалюцыя, як мора, ускалыхнуўшае ўсё, што было на дне, зноў апусціла на дно тое, што там было. Хто быў нічым, той і застаўся нічым $^{62}$ (Val'tar, 2009, p. 116).

Two extremely strong fragments of the novel describe the madness of violence into which the participants of the revolutionary events fell.

The first of them we find in those Tuhoŭski's memoirs. The events in Kharkov, temporarily occupied by Denikin, are described:

У сэрцы Тугоўскага рабілася горка. Вось якая псіхалогія ў гэтых людзей, якія называюць сябе інтэлігентамі. Вось яны, прыгожыя дамы! Яшчэ на іх вачох валяліся прыкрытыя рагожай, акрываўленыя трупы матросаў і жаўнераў, а яны хацелі новых ахвяр, новай крыві. Па вуліцах гналі на расстрэл кучкі людзей (хто ведае, вінаватых ці не), нёслых галаву за ідэю ці, можа быць, проста за якую-небудзь помсту якога-небудзь узлаванага абывацеля. Іх вялі светлым, радасным, сонечным днём, калі ўсё казала аб

58 Valtar referred to parts of his novel as 'quadras' rather than more conventionally as 'sections'.

59 'Then came the thunder. War has come'.

60 'And here - suddenly revolution. A refreshing storm swept through the air, igniting many brave hearts with a thirst for freedom and light'.

61 'And suddenly, unexpectedly, having thrown some armoured trains, having left corpses on the streets, the Bolsheviks handed over Kharkov'.

62 'The revolution has entered its shores... The revolution, like the sea, stirred up all that was at the bottom, again lowered to the bottom what was there. He who was nothing is nothing'. 
жыцці, калі ў мясцовых садах гуляў разубраны натоўп і чырыкалі весела птушкі, вялі на круты бераг... і там кулямётам касілі, як жывёлу ${ }^{63}$ (Val'tar, 2009, p. 115).

The fragmentary phrase, which chokes in its own semantics 'and there was a machine gun mowed them like cattle' (two trails: 'mow like grass' and 'kill like cattle' overlaid one on one) aptly conveys the horror that Tuhoŭski was wrapped in. How can you give yourself up to joyful and sunny days, even in Prague, far from the revolutionary maelstrom, after such an experience? The second passage describing the violence during the revolution is perhaps even more impressive, because this time we hear the cynical 'voice' of a participant in the events - a Ukrainian emigrant, a former soldier of Petliura's army, telling about his own act quite calmly, without a shadow of pity and anguish:

Прывялі іх у штаб. Чорт іх ведае: можа, сапраўды шпіёнкі якія-небудзь. Мы нават не маглі паверыць, што гэта жанчыны. Хто ведае, можа, гэта пераапранутыя мужчыны? Загадалі ім зараз распрануцца. Дрыжачы ад страху і сораму, яны распрануліся і стаялі перад намі, як пакорныя авечкі. Зрабілі допыт. Усё аказалася ў парадку. Мы ім паверылі. Начальнік, кончыўшы допыт, усміхнуўся і сказаў: „Ну, хлопцы, думаю, што на допыце вы пакажаце сябе інтэлігентнымі ў адносінах да гэтых трох дам. Iх трое - і вас трое. Выбірайце сабе любую".

3 гэтымі словамі ён выйшаў $з$ пакою... Засталіся мы адны, пераглядаемся, смяемся на свае ахвяры... Што ж рабіць з імі? Вазіць іх з сабой? Не такі час, але наогул у нас жанчын няма... Бог ведае, калі мы іх бачылі. Стаім і глядзім, выбіраем. Нарэшце, выбралі. Мне трапілася нейкая спявачка. Артыстка! Жыццё сваё не меў артыстак, нават не бачыў, а тут на табе - шчасце прываліла... Ну, вось і паспрабаваў я.

Апавядальнік замаўчаў і пачаў цягнуць раз за разам даўгую люльку.

- А далей што было? - нецярпліва запытаў чысты голас.

- Далей пайшло ўсё добра, яна мне на памяць дала залаты гадзіннік, яна спявала ў маіх абоймах, як птушка ў абоймах кошкі, рамансы аб каханні. Гэта была, напэўна, яе лебядзіная песьня, бо назаўтра зрання...

Ён замаўчаў і пачаў падкладваць вуголле. Вугаль успыхнуў, і ў чырвонай печцы загуло.

- Што назаўтра зрання? - запытала некалькі чалавек.

- Назаўтра мы адступілі ад гэтага мейсца.

63 'It was made bitter in Tuhoŭski's heart. That's the psychology of these people who call themselves intellectuals. Here they are, beautiful ladies! Even before their eyes lay, covered with matting, bloody corpses of sailors and soldiers, and they wanted new victims, new blood. In the streets a bunch of people were driven to their execution (who knows, guilty or not), demolished the head for an idea, or maybe just as the revenge of some angry man in the street. They were led on a bright, joyous, sunny day, when everything spoke of life, when a smart crowd walked in the local gardens and birds chirped merrily, they were led to a steep bank... and there was a machine gun that mowed them like cattle'. 
- А яна? - запытаў Серада з кута. Кінуўшы гуляць, ён прыслухваўся да размовы. - Ты яе забіў?

- Яе? - неахвотна перапытаў апавядальнік, выбіваючы люльку. - Не... Я на развітанне толькі перацягнуў яе пару раз. Але яе, здаецца, потым расстралялі ${ }^{64}$ (Val'tar, 2009, p. 157).

History in its immediate reality is as much a nightmare for Tuhoŭski as it is for Stephen Daedalus in Joyce's Ulysses, from which he is vainly trying to wake up. He does not see himself and his Prague acquaintances as subjects of history, only as possible victims:

Колькі іх, гэтых працавітых павукоў, павуціну каторых так злітасна змятае мятла выпадку? Я пачынаю думаць, што мы ўсе тут, у Празе, - роджаныя пад Сатурнам, што ўсе мы загінуўшыя для Бацькаўшчыны людзі, i, можа быць, не адзін з нас пойдзе па дарозе айца Кірылы... Хто выйдзе прарокам з нашага пражскага Назарэту? Я думаю - ніхто. Большасць з нас пакладзе свае косці на чужыне, меншасць будзе стыдацца апрануцца ў бацькавы кажух, бо ён смярдзіць. Так пройдзем мы, пражане, па свеце, як пыл, - не нацешыўшы нікога ні сваім росквітам, ні сваёй моцай, толькі жаласцю ці пракляццямі ${ }^{65}$ (Val'tar, 2009, p. 216).

64 'Brought them to headquarters. Hell, maybe they were spies. We couldn't even believe they were women. Who knows, maybe they're men in disguise? Ordered them to undress now. Trembling with fear and shame, they undressed and stood before us like obedient sheep. Did the interrogation. Everything was in order. We believed them. The chief, having finished the interrogation, smiled and said: "Well, guys, I think that in the interrogation you will show yourself intelligent in relation to these three ladies. There are three of them - and three of you. Choose any.'

With that he left the room... We were left alone, looking at each other laughing at their victims... What to do with them? Carry them with you? It's not that kind of time, but we don't have any women... God knows when we saw them. Stand and stare, select. Finally, chose. I came across a singer. Artist! In all my life there were no artists, did even not see, and here on you - halt happiness... Well, I tried.

The narrator paused and began to smoke his long pipe again and again..

- What happened next? - a clear voice asked impatiently.

- Everything was well, she gave me a golden clock for the memory, she sang in my arms as a bird in the embraces of a cat, romances about love. It was probably her swan song, because it is already tomorrow morning...

He paused and began to add coals. The coal is ignited, and it is buzzed in the red stove.

- What's tomorrow morning? - several people asked.

- The next day we retreated from this place.

- And she? - Serada asked from the corner. He stopped playing and listened to the conversation. - Did you kill her?

- Her? - the narrator asked reluctantly, knocking out his pipe. - No. ... I just hit her a couple of times. But she seems to have been shot afterwards'.

${ }^{65}$ 'How many of them, those industrious spiders whose webs are so pathetically swept away by the broom of chance? I begin to think that we are all here in Prague - born under Saturn, that we are all lost for the Homeland people, and maybe not one of us will follow the path of father Kiryl... 
The feeling of the insignificance of his own existence in comparison with the power of historical events is conveyed by the following Tuhoŭski's words: 'Што такое быў ён, Пётра Тугоўскі, у велізарнай чашы жыцця? Адзінокая пясчынка, якая ляжала без усякага руху ў агульнай масе пяску'66 (Val'tar, 2009, p. 247).

The national narrative, though sometimes nondescript, dreamy in its 'smells of honey' and 'future generations in white clothes with flags and banners' was the desperate way to wake up from the nightmare of violent, unpredictable history for the Belarusian intelligentsia, which gave its discussions such fervour and persistence.

Zahorski - the main antagonist of Tuhoŭski, with whom he struggles for love of Viarchoŭskaja, whom he knew from his childhood and who almost all his life was an embodiment of contemptible, but and enviable, unattainable 'high society': many times he insulted the feelings of the main hero of Born under Saturn, but, perhaps, the major insult he inflicted was at the beginning of the novel. Tuhoŭski decides to tell Zahorski his theory of congenital infelicitous people, among whom he counts himself, and hears the following words in response: 'Ну, ведаеце што... - не даў яму скончыць Загорскі. - Выбачайце, я не маю часу з вамі больш гутарыць. Але я вам раджу с вашай тэорыяй звярнуцца ў Празе ў Інстытут псіхічных доследаў' ${ }^{\prime}$ (Val'tar, 2009, p. 96).

Tuhoŭski, in whom his friends not just find out and recognize a philosopher and poet (see: Val'tar, 2009, p. 193; 195; 197; 215; 220), not on education, and, even, not on the written texts, but according to world perception, modality of feelings and life, that is - to an expert of the internal life, a peculiar 'Daedalus diver' of his own sincere world, the future doctor Zahorski opposes another type of knowledge in which space he is deprived of the right to an explanation of the soul, and all his sleek despair and theoretical constructions can be expressed in one word - 'madman'. The personal and social conflict passes into an epistemic plane. It is this fear of new knowledge, which can take away from him the direct connection with his own body, with his own feelings and thoughts, expropriate them into causal ranks, erase from them the marks of peculiar properties, individuality, 'I', that forces Tuhoŭski to separate himself from his being in advance, to recognize his possible defeat in advance. He voluntarily surrenders his own life to science which does not yet exist:

Who will be a prophet from our Prague Nazareth? I think nobody. Most of us will lay our bones in a foreign land, a minority will be ashamed to dress in a father's sheepskin coat, as it stinks. Thus we, the citizens of Prague, will pass through the world like dust, without pleasing anyone with either our prosperity or power, only with pity or a curse'.

66 'What was he, Piotr Tuhoŭski, in the great bowl of life? A single grain of sand that lay without any movement in the total mass of sand'.

67 “"Well, you know what". Without letting him finish, Zahorski said "I'm sorry, I don't have time to talk to you anymore. But I advise you to apply to the Institute of Psychical Research in Prague with your theory'. 
Людзі не хочуць прызнаць, што лёс існуе і кіруе жыццём. Яны кажуць: мы вольныя птушкі, давайце будзем лётаць пад небам, над нязведанымі краямі. Можа быць, гэта i хвароба, можа быць, трэба спяваць гэтай безразважнасці песню, але ўсё ж гэта безразважнасць. Закон жыцця строгі і бязлітасны, як суддзя. Цяпер трэба даведацца, дзе ў чалавека знаходзяцца крыллі? Крыллі гэтыя знаходзяцца ў мозгу. Так, у мозгу... [...] Я бачыў калісьці фатаграфію мозгу ангельскага пісьменніка Шэкспіра і простага ангельскага работніка. Мозг быў аднолькавых размераў, але ў Шэкспіра звіліны ішлі правідловымі і выразнымі лініямі, у той час як у работніка яны былі невыразныя і зусім не правідловыя. [...] І можа быць, мілыя сосны, праз 300 гадоў, калі ўжо і вас не будзе, у лес прыйдзе чалавек і раскажа, што ён прыдумаў такія праменні, як зараз рэнтгенаўскія, якія праходзяць праз чарапны кошык і адразу паказваюць, што гэты чалавек будзе вераб’ём, гэты - каршуном ці сакалом... Можа быць, тады вераб'ёў будуць нішчыць, як непатрэбных? Тады запануе толькі здаровая, разумная людскасць і жыццё стане прыгожым. Аб гэтым нават думае новая навука. Але пакуль гэтага няма. Вераб'і жывуць і спакойна сабе чырыкаюць... ${ }^{68}$ (Val'tar, 2009, pp. 120-121).

In the same pseudo-medical metaphors, the author of Born under Saturn describes the thoughts and state of Tuhoŭski in the first part of the first 'quadra' of the novel, where the author's speech is most close to Tuhoŭski's own words:

Ён не чуў, як мокрыя кроплі цяклі з яго старога капелюша за каўнер. Ён не чуў, бо цягучыя, мокрыя думкі паўзлі горш за дождж у яго мазгу, і мучылі яго, і спынялі яго на вуліцы $^{69}$ (Vaítar, 2009, p. 91);

Так бацыла, папаўшая ў кроў, прыгнячае чалавека, прыхіляе яго галаву, яго залёты, робіць яго маларухлівым [...] Так папала бацыла ў сэрца і мозг Тугоўскага, і так яна апанавала ім, так яна прымусіла яго схіліць да зямлі галаву і цягнуцца бязвольна

68 'People do not want to admit that fate exists and governs life. They say: we are free birds, let us fly under the sky, over unknown lands. It may be a disease, it may be necessary to sing a song to this recklessness, but it is still recklessness. The law of life is strict and merciless as a judge. Now need to know, where have the people got wings? These wings are in the brain. So, in the brain... [...] I once saw a photograph of the brain of the English writer Shakespeare and a simple English worker. The brain was the same size, but in Shakespeare's brain the convolutions were regular and clear lines, while in the worker's brain they were barely visible and not at all regular. [...] And maybe, dear pines, in 300 years, when none of you will be, a man will come to the forest and say that he would invent such rays as now x-rays that pass through the skull and immediately show that this person will be a sparrow, this one - a hawk or a falcon... Maybe, then sparrows will be killed, as unnecessary? Then only healthy, intelligent humanity will reign and life will become beautiful. The new science even thinks about it. But not yet. Sparrows live and tweet quietly...'

69 'He did not feel the wet drops trickling from his old hat behind his collar. He did not hear, because viscous, wet thoughts crept worse than rain in his brain, and tormented him, and stopped him in the street'. 
дахаты. Бацыла самагубства, папаўшая ў мозг, не так хутка пакідае чалавека. Яна папала ў мозг Тугоўскага і грызла, грызла яго ўсю дарогуํ( (Val'tar, 2009, p. 92).

'Father' Kiryl is being held prisoner of the same reductive discourse. On his friend's confession he replies almost with the same tough words as Zahorski: 'Так, брат, неўрастэнія ў цябе, вострая неўрастэнія. Можаш ісці да любога доктара: ён скажа табе тое самае. Ты думаеш, што кажаш страшэнна мудрыя рэчы. Ніколькі, выбачай. Твая, з дазволу казаць, філасофія не мае ў сабе нічога цікавага' (Val'tar, 2009, p. 124) ${ }^{71}$. And Tuhoŭski's love to Viarchoǔskaja he humiliates by the following dictum: 'Падумай, каго там кахаць? Па-мойму, гэта толькі пахучы кавалак мяса' (Val'tar, 2009, p. 195).

Man, as a bad piece of meat is the terrible image, which Tuhoŭski is struggling with. An image that encodes all those intellectual traps of behaviourism, biological reductionism, racism into which interwar European thought has fallen.

\section{Intellectual: Indignity or Fate?}

Born under Saturn to a certain extent can be considered as a metatext: the novel is woven from plots, references, hidden and explicit quotes, fragments from other texts, woven on the basis of the reader's experience of an intellectual of the early $20^{\text {th }}$ century from the Russian-European borderlands. 'Гэтак не прасякнуты “літаратуршчынай” ніводны вядомы нам айчынны дакараткевіцкі твор"73 (Ščur, 2011, p. 587). But unlike similar metatexts of modernity, the wide use of quotations in Born under Saturn is motivated not by the logic of the postmodern game, but by the features of behaviour and ways of self-consciousness of the characters of the novel. An intellectual - in this case Belarusian, but we can say more broadly: from the periphery of the former Russian Empire - is a 'man of the book', sometimes even a 'man from the book'. His life is a constant test of plots and ideas from reading, as well as vice versa - the test of plots and ideas of favourite books in his own life.

Almost from the first pages of the novel we see how Tuhouski measures his feelings by the standards of his own reading experience. The scenes of student life in the hostel remind him of Dostoevskii's Dead House (Val'tar, 2009, p. 94), he evaluates them already through Gor'kii's text: “Лепш быць “на дне” - бадзягай, але мець

70 'So the bacillus, gets into the blood, oppresses and suppresses a person, bends his head, his aspiration, makes him sedentary [...] And so the bacillus got into Tuhouski's heart and brain, and so it possessed him, so it made him bow his head to the ground and go slowly and limply home. The suicide bacillus, once in the brain, does not leave a person so quickly. It got into Tuhouski's brain and was gnawing, gnawing him all his way home'.

71 'Yes, brother, you have got neurasthenia, an acute neurasthenia. You can go to any doctor and he will tell you the same thing. You think you're saying terribly wise things. Not at all, sorry. Your philosophy, if I may say so, has nothing interesting in it'.

72 'Think, who is there to love? In my opinion, it is only an odorous piece of meat'.

73 'No one national, known to us before Karatkievič's work, is so impregnated with literature'. 
у сэрцы агонь, мець яшчэ святы парыў узлётаў'74 (Val'tar, 2009, p. 94). His ironically negative attitude to the BNR ministers he wraps in Gogol"s prose, comparing them with Sabakevich (Val'tar, 2009, p. 229), then with Afanasii Ivanovich Tolstogub (Val'tar, 2009, p. 232). In the latter case, the image of Tolstogub, in which he 'dressed' Piotr Kračeŭski, so rooted in his eyes to the real person that, even being grateful to him for the return of the scholarship, Tuhoŭski continues to see in him the same literary character, and in his wife - Pulcheria Ivanovna: 'Бабулька таксама трэсла яго руку, нягледзячы на тое, што ў гэты час бліны гарэлі на пліце. Тугоўскі глядзеў на яе ледзь не са слязамі на вачох, думаў: "Мілая, мілая Пульхерыя Іванаўна...”"75 (Val'tar, 2009, p. 233). The meaning of his life he tries to find in the words of Dostoevskii 'suffering cleanses everything' (Val'tar, 2009, p. 223), then in the 'simplifying' of Tolstoi, then - in the image of Rudin by Turgenev (Val'tar, 2009, p. 248). Even in his suicide note, he cannot resist the temptation to make a reference to Nietzsche by calling it Confession of a Suicide. The Book for Everyone and No One. Tuhoŭski himself in the eyes of his friends also looks like the embodiment of literary heroes - whether Hamlet (Val'tar, 2009, p. 123, 192), or Faust (Val'tar, 2009, pp. 213-214). Even his disappointment in love for Viarchoŭskaja Tuhoŭski expresses with a help of a quote from Kupala 'Гэткім шчырым каханнем яе атуліў... А яна... А яна была толькі... дзяўчынай!...76 (Val'tar, 2009, p. 189). And Viarchoŭskaja herself describes her biography, the genesis of her ideology as a reader's experience: ‘Я вырасла на кнігах Пісарава, Чарнышэўскага, Маркса' ${ }^{97}$ (Val'tar, 2009, p. 254).

It should be noted that in Born under Saturn one can find a suggestion why young Belarusian literature was able to find its way to the heart of the intelligentsia so quickly. Here we see how, as if to spite the author of Grammatology (Derrida, 1967), the phoneme has overcome the letter: the Russian text of the beginning of the $20^{\text {th }}$ century existed mainly in the form of a song, and this modality of perception of information, which was different from the lonely reading, had other results:

Песня палілася прыгожымі хвалямі, падымаючыся ўсё вышэй і вышэй у столь, выходзячы праз адчыненыя дзверы вузкага пакою ў калідор, і панеслася далей у чужое ёй чэшскае паветра. Чулася, што разам з песняй падымаліся думы спевакоў і несліся на далёкую Бацькаўшчыну, у далёкае мінулае... ${ }^{78}$ (Val'tar, 2009, pp. 134-135);

74 'It is better to be "at the bottom" as a tramp, but to have fire in your heart, to have a holy rush of elations'.

75 'The old woman also shook his hand, despite the fact that at this time the pancakes were burning on the stove. Tuhoŭski looked at her almost with tears in his eyes and thought: "Dear, dear Pulcheria Ivanovna..."”

76 'A sincere love she was embraced... And she... And she was only... a girl! ..'

77 'I grew up on the books of Pisarev, Chernyshevskii, Marx'.

78 'The song flowed in beautiful waves, rising higher and higher into the ceiling, leaving through the open door of the narrow room into the corridor, and rushed on into the alien Czech air. It was felt 
Хор усё больш і больш прамаўляў да слухачоў; здавалася, што з грудзей кожнага спевака вырывалася слова з асаблівым націскам, з асаблівай верай у прыгожасці песні.

Хацелася верыць, хацелася плакаць ад радасці, што гэта так будзе, інакш і не можа быць:

Зацвіце наш край, як сонца, Пасля непагоды...

I разам з хорам уся істота - радасная, шчаслівая, узмацаваная - падымалася на крылах да сонца $з$ гімнам неўміручай праўды:

Ў роўнай сіле, ў роўнай праўдзе, Між усіх народаў... ${ }^{79}$ (Val'tar, 2009, pp. 177-178).

The Belarusian song was like a directly audible voice of the people, whose soul was so long and vainly sought by Russian literature, which is eagerly read by the heroes of the novel. To join this people, to merge into unity with them it was not necessary to engage in 'going to the people' - it was necessary to pick up the words of the song, to join the voice to the general chorus. Secondly, the joint singing, especially the general performance, gave a sense of unity of feelings and thoughts - that unity which could never be found while reading 'to ourselves'.

In the gap and tension between the two moments, two emotional registers - 1) general performance of the song-poem, a lyrical unity with the object of glorification - the Belarusian people in their desires, sorrow, ambitions and destiny, the unity of all listeners, and the resonance of their feelings; 2) an escape into the solitude of his intelligence and erudition, wide, but indefinite life and ideological horizons - it was found a place by the main tragedy, the main question of the Prague students: who is against people of the Belarusian intelligentsia, its role and vocation? Two alternative answers to the question in the novel are personified by 'father' Kiryl and Tuhouski himself (only at the end will he change his views), on the one hand, and Tamaševič - on the other. For Kiryl Buračeŭski, 'intellectual' is an insult. Modern ailments and inadaptability to life enter into the body of the people through intellectual flesh, an intellectual way of life and spiritual organization:

Я ў табе памыліўся. Я думаў, што ты з працоўных, з сялян ці работнікаў, што ты моцна, па-дзедаўску, гатоў чапляцца за жыццё, нягледзячы ні на якія мукі й болі. Я думаў, што ты прыйдзеш у нашу грамаду і станеш у шэраг тых, хто гатоў гінуць за работнікаў, як кажуць, за вялікую справу ўсялюдскага кахання... А ты - інтэлігент,

that together with the song the thoughts of the singers rose and rushed to the distant Homeland, to the distant past...'.

79 'The chorus spoke more and more to the audience; it seemed as if a word with a special emphasis, with a special belief in the beauty of the song, was bursting from the breast of each singer.

I wanted to believe, wanted to cry from joy that it would be so, otherwise it can not be:

Our land will bloom like the sun after bad weather...

And with the chorus the whole being - joyous, happy, stronger - rose on wings to the sun with the hymn of immortal truth:

In equal power, in equal truth, Among all Nations...' 
хворы інтэлігентнымі хваробамі. Такіх інтэлігентаў я цярпець не магу. Тады жадаю табе шчаслівай смерці, як і ўсякаму інтэлігенту [...] Гэта тэорыя знайшла ў тваім „я” адпаведны грунт, таму што ты хворы інтэлігент. Але ўсё ж, думаю, пакалупаць цябе пальцам - дык усярэдзіне тваёй акажацца здаровы селянін ${ }^{80}$ (Val'tar, 2009, p. 124).

Intelligence itself for Buračeŭski is synonymous with disease, biological degradation. Tuhouski, who for some time shared these views of Buračeŭski, even believes that the apparent syphilis, with which he is supposedly ill, makes him identical with 'bourgeois' intellectuals (Val'tar, 2009, p. 202). Also noteworthy is Tuhoŭski's vision of Belarusian students on the university benches, in the image of the confrontation of the natural-rural youth, health and fun with the dangers of knowledge: 'Беларусы 3 чырвонымі вясковымі тварамі, маладыя і вясёлыя, глядзелі на ўсё з адкрытымі ратамі, як вясковыя бабы на дзіва. Яны ўсё прымалі радасна, без задніх думак, яшчэ ні ў чым не расчараваныя, як дзеці, якія спакойна глядзяць на вагонь і не ведаюць, што гэты вагонь іх апаліць'81 (Val'tar, 2009, p. 162).

The intellectual is also separated from the people by his sensual organization: his artificial fastidiousness separates him from the 'broad masses' and Belarus itself. The symbol of this disgust for Tuhoŭski and Buračeŭski will be the following episode from Prague student life: 'Казалі пра аднаго студэнта з Прагі, які, заехаўшы да бацькіселяніна, не мог апрануць кажуха. “Смярдзіць”, - казаў ён сярдзіта. Гэты студэнт - правобраз тых, якія вернуцца пасля яго на Бацькаўшчыну. “Бедная Беларусь, падумаў Тугоўскі, - калі яна мае такіх сыноў" 82 (Val'tar, 2009, pp. 164-165).

The unwillingness to wear his father's 'smelly' sheepskin coat for Tuhoŭski and Buračeŭski is one of the main symbols of the illness and doom of the Belarusian students (see: Val'tar, 2009, p. 194, 216, 256). Excessive, far-fetched intelligibility, picked up by Belarusians, as if that trouble, in Prague, tears off from its roots, from simple country life, forces them to put on someone else's clothes, to betray their true essence:

80 'I was wrong about you. I thought you were one of the workers, of the peasants or labourers, that you were strongly, like your grandfathers, ready to cling to life, in spite of any torment and pain. I thought that you would come to our community and join the ranks of those who are ready to die for the workers, as they say, for the great cause of national love... And you are an intellectual, sick with intellectual diseases. I can't stand such intellectuals. Then I wish you a happy death, as well as any intellectual [...] This theory has found in your "I" appropriate ground, because you are a sick intellectual. But nonetheless, I think, if somebody would dig into your life - then there would be a healthy peasant inside you'.

81 'Belarusians with red village faces, young and cheerful, looked at everything with open mouths, like village women on a miracle. They took everything joyfully, without second thoughts, still not disappointed in anything, like children who calmly look at the fire and do not know that this fire will burn them'.

82 'They said about one student from Prague, who, visiting his father, a peasant, could not wear his sheepskin coat. "It stinks", he said angrily. This student is a prototype of those who will return after him to their Homeland. "Poor Belarus", thought Tuhoŭski, "if she has got such sons"”. 
- Не ў гэтым справа, - прадоўжыў Кірыла. - Калі б гэты Бурак заставаўся сабой і нават сярод арыстакратаў калупаў пальцам у носе, гэта можна было толькі вітаць. Але калі гэты просты палескі мужык Бурак нацягвае на сваю шырокую руку рукавічкі, калі ён хоча курчыць з сябе арыстакрата, графа, - тады гэта толькі маўпаванне. Над гэтым трэба смяяцца, праз слёзы. Чаму? Таму, што гэты чалавек - косць ад косці, кроў ад крыві простага народу, не хоча ісці з ім, не думае змагацца за яго долю, не хоча стаць у шэраг грамадскіх працаўнікоў ${ }^{83}$ (Val'tar, 2009, p. 170).

And neither Buračeŭski nor Tuhoŭski see that this cultivated by them theme of culture as disease, degradation and isolation from natural, genuine and healthy life is precisely intellectual, par excellence, and in this subject they agree with such masters of the intellectual life of Europe, as Rousseau, Schopenhauer, Nietzsche, Spengler, or - Ladislav Klima, to take an example from the same context of interwar Prague.

The words 'bone from bone, blood from the blood of the common people' reflect the main mistake of Kiryl Buračeŭski. He, like Tuhoŭski, most of the action of the novel interprets the question of the intelligentsia in the old class categories - intellectuals cannot be, they can only be born: 'лацінскае слова і гісторыя яшчэ не робяць $з$ селяніна інтэлігента, мужык і пасля ўніверсітэта застаецца тым самым мужыком, як і да паступлення ў яго '84 (Val'tar, 2009, p. 182). 'Peasant sons' who have acquired education and a certain culture are either temporary, mistaken transformations, or a betrayal of their roots, renegacy. To return to their true essence, they need to "throw off this proud and ugly label of "intellectual"' (Val'tar, 2009, p. 168). While the representatives of other estates who are trying to find a way to understand their own people - are a priori 'брахуны' ('liars') (Val'tar, 2009, p. 168). They are deprived of the opportunity to express the truth, because in the beginning they had hidden the truth about their social origin.

This nihilistic approach in the novel is opposed to the views of Tamaševič. Instead of Duračeŭski's class-genealogical definition of intelligentsia, he offers his own, relational: ‘Кожны чалавек, хто задумваецца над самім сабой, над людскім існаваннем, хто жыве не толькі для бруха, але крыху і для духа, ужо ёсць думаючая частка народу ${ }^{85}$ (Val'tar, 2009, pp. 212-213). An intellectual is not born, but becomes through overcoming this specific social and biological being, through a breakthrough

83 '- That's not the point, - continued Kiryl. "If this Burak would stay himself, and pick his nose even among the aristocrats, then it could be approved. But if this simple Polish peasant Burak pulls gloves on his broad hand, if he wants to pretend to be an aristocrat, a count - then this is only aping. It is necessary to laugh at it, through tears. Why? Because this man is bone from bone, blood from the blood of the common people, does not want to go with them, and does not think to fight for their share, does not want to join the ranks of public workers'.

84 'the Latin word and history don't make of the peasant an intellectual, a peasent even after his graduation remains the same peasant'.

85 'Every person who thinks about himself, about human existence, who lives not only for the belly, but also for the spirit, is already a thinking part of the people'. 
beyond common, joint definitions and social losses, through the acquisition of his 'individuality, his human face' (Val'tar, 2009, p. 213). The people consists of units, and the more among these units of thinking individuals, the more the people turns into a nation: ‘3'яўляецца ў народзе група адукаваных людзей, з'яўляецца ў групе пэўная воля, моцнае жаданне да жыцця, і гэта воля перадаецца народу. Вось тады 3'яўляецца і нацыянальнасць ${ }^{\prime 86}$ (Val'tar, 2009, p. 134). Tamaševič does not believe Tuhoŭski's life project of 'simplifying', returning to the Belarusian people, as 'how could we simplify, when we all came from the common people and from the point of view of any Russian are very 'simple' (Val'tar, 2009, p. 213). The 'common people' are composed of a social mass devoid of their own intelligentsia and high culture - it is only an object for external political manipulation, a 'return' to such a people, is only a rejection of one's own subjectivity. Therefore, Tamaševič opposes to Tuhoŭski's 'simplifying' his own existential project of improvement - 'даўгі, паслядоўны шлях

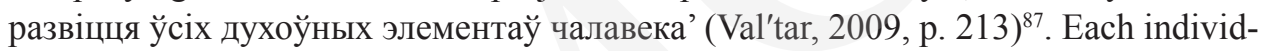
ual and people as a whole should take the path of development and manifestation of their own individuality, their spiritual potentials.

Translated into English by Marharyta Svirydava

\section{List of sources}

G-be [T. Hryb]. (1919). Dwa hady rewalucyi. Hramadzianin, 17, 14.03.1919. Vilnia.

Gryb, Tamaš. (2017). Vybranae. Mìnsk: Knìgazbor. [Грыб, Тамаш. (2017). Вығранае. Мінск: Кнігазбор].

Masaryk, Tomáš Garrigue. (1926). Sebevražda hromadným jevem společenským moderní osvěty. Taken from: http://kramerius4.nkp.cz/search/i.jsp?pid=uuid:3d8065a0-26ad-11e4-8e0d-005056827e51 (accessed: 30. 07. 2018).

Mickiewicz, Adam. (1917). Pan Tadeusz. London and Toronto: M. Dent.

Mìckevič, Adam. (1998). Pan Tadevuš, abo Apošni najezd u Litvie. Minsk: Biel. fond kuĺtury. [Міцкевіч, Адам. (1998). Пан Тадэвуш, або Апошні наезд у Літве. Мінск: Бел. фонд культуры].

Val'tar, Viktar. (2009). Rodžanyâ pad Saturnam. In: Viktar Val'tar. Vybranyâ tvory. Mìnsk: Knìgazbor. [Вальтар, Віктар. (2009). Роджаныя пад Сатурнам. У: Віктар Вальтар. Выбраныя творы. Мінск: Кнігазбор].

\footnotetext{
86 'There a group of educated people appears among the people, then a certain will, a strong desire for life appears in the group, and this will is transmitted to the people. That's when nationality appears'.

87 'debts, a consistent path of development for all spiritual elements of man'.
} 


\section{References}

Anderson, Benedict. (1991). Imagined communities: reflections on the origin and spread of nationalism. (Revised and extended. ed.). London: Verso.

Bahtin, Mihail. (2015). Problemy poètiki Dostoevskogo. Sankt-Peterburg: Azbuka. [Бахтин, Михаил. (2015). Проблемы поэтики Достоевского. Санкт-Петербург: Азбука].

Baroǔka, Vanda. (2014). Raman 'Rodžanyâ pad Saturnam' Viktara Val'tara âk žanravastylëvy fenomen. Białorutenistyka Białostocka, 6, pp. 69-78. [Бароўка, Ванда. (2014). Раман “Роджаныя пад Сатурнам” Віктара Вальтара як жанравастылёвы феномен. Biatorutenistyka Białostocka, 6, s. 69-78].

Buča, Andrej. (2012). Belaruskaâ dyâspara ǔ službovyh spravazdačah čèhaslavackìh naglâdnyh organaǔ (1920-1930-â gg.). In: Anatolij Sal'kov, Oleg Ânovskij (ed.). Rossijskie i slavânskie isledovaniâ: nauč. sb., vyp. 7 (pp. 297-310). Minsk: BGU. [Буча, Андрей. (2012). Беларуская дыяспара уу службовых справаздачах чэхаславацкіх наглядных органаў (1920-1930-я гг.). В: Анатолий Сальков, Олег Яновский (ред.) Российские и славянские иследования: науч. сб., вып. 7 (с. 297-310). Минск: БГУ].

Derrida, Jacques. (1967). De la grammatologie. Paris: Les Éditions de Minuit.

Kilias, Jarosław. (2013). Tomáš Garrigue Masaryk jako socjolog. Roczniki Historii Socjologii, 3, pp. 81-109.

Kolenovská, Daniela; Plavec, Michal. (2017). Běloruská emigrace v meziválečném Československu: Studie a dokumenty. Praha: Charles University in Prague, Karolinum Press.

Lovejoy, Arthur. (2006). The Great Chain of Being: A Study of the History of an Idea. Cambridge, MA: Harvard University Press.

Paškevič, Ales'. (2002). Belaruskaâ planìda Viktara Val'tara, Rodnae slova, 7, p. 28. [Пашкевіч, Алесь. (2002). Беларуская планіда Віктара Вальтара, Роднае слова, 7, с. 28].

Plamper, Ân; Šahadat, Šamma; Èli, Mark (ed.). (2010). Rossijskaâ imperiâ čuvstv: podhody k kul'turnoj istorii èmocij. Cb. st. Moskva: Novoe literaturnoe obozrenie. [Плампер, Ян; Шахадат, Шамма; Эли, Марк (ред.). (2010). Российская империя чувств: подходь к культурной истории эмоций. Сб. ст. Москва: Новое литературное обозрение].

Plamper, Jan. (2012). Geschichte und Gefühl: Grundlagen der Emotionsgeschichte. München: Siedler Verlag.

Reddy, William. (2001). The Navigation of Feeling: A Framework for the History of Emotions. Cambridge: Cambridge University Press.

Rosenwein, Barbara. (2006). Emotional Communities in the Early Middle Ages. Ithaca, New York: Cornell University Press.

Ščur, Maks. (2011). Viktar Val'tar, al'bo Samazabojčy tèrakt zapavolenaga dzeân'nâ. Zapisy Belaruskaga İnstytutu Navukì j Mastactva, 34, pp. 585-656. [Шчур, Макс. (2011). Віктар Вальтар, альбо Самазабойчы тэракт запаволенага дзеяньня. Запісы Беларускага Iнстылуту Навукі й Мастайтва, 34, с. 585-656]. 
Pobrane z czasopisma Studia Bia?orutenistyczne http://bialorutenistyka.umcs.pl Data: 26/04/2023 15:44:35

The Birth of Individuality from the Spirit of Belarusianness: the Life Trajectories...

Zorin, Andrej. (2016). Pô̂vlenie geroâ: Iz istorii russkoj èmocional'noj kul'tury konca XVIII - načala XIX veka. Moskva: Novoe literaturnoe obozrenie. [Зорин, Андрей. (2016). Появление героя: Из истории русской эмоциональной культуры кония XVIII - начала ХІХ века. Москва: Новое литературное обозрение].

Article submission date: 5 October 2018 